\title{
Do Payday Loans Cause Bankruptcy?
}

\author{
Paige Marta Skiba Vanderbilt University \\ Jeremy Tobacman University of Delaware
}

\begin{abstract}
Payday loans are used by millions of Americans every year despite their annualized interest rates of several hundred percent. We provide new evidence on the consequences of payday borrowing and the determinants of personal bankruptcy. Using an administrative panel data set of loan records in a regressiondiscontinuity design, we estimate that payday loans increase personal bankruptcy rates by a factor of two. We assess possible mechanisms and find the most support for a novel one: payday loan access appears to induce bankruptcy filings by worsening the cash flow position of the household.
\end{abstract}

\section{Introduction}

Usury laws are often adopted to restrict high-interest lending such as payday loans. With annual percentage rates (APRs) of 400-600 percent, payday loans carry some of the highest interest rates available on formal credit products. Despite this, about 10 million American households borrow using payday loans each year, and payday lenders have more storefronts in the United States than McDonald's and Starbucks combined (Pew Charitable Trusts 2012; Lusardi and de Bassa Scheresberg 2013).

This paper contributes new evidence on both the impact of payday loan access

We would like to thank David Abrams, Ken Ayotte, Dan Benjamin, Neil Bhutta, David Card, Kitt Carpenter, Raj Chetty, Michael Clemens, Stefano DellaVigna, Ed Glaeser, Michael Greenstone, Zack Grossman, Joseph Hennawi, Joni Hersch, Mark Hoekstra, Pamela Jakiela, Kory Kroft, David Laibson, David S. Lee, Ulrike Malmendier, Paco Martorell, Justin McCrary, Markus Mobius, Ed Morrison, Sendhil Mullainathan, Kate Nicholson, Devin Pope, Matthew Rabin, Steve Raphael, Emmanuel Saez, Anna Skiba-Crafts, Mel Stephens, Justin Sydnor, Kip Viscusi, Maisy Wong, and Jonathan Zinman for many helpful conversations and seminar audiences at the Bank of Canada, the Federal Reserve Bank of Chicago, Harvard University, the Institute for Fiscal Studies, the London School of Economics, Oxford University, the RAND Corporation, the Wharton School of the University of Pennsylvania, Yale University, and the University of California, Berkeley, for valuable feedback. Susan Payne Carter, Katie Fritzdixon, Jonathan Leung, Caroline Malone, John Roberts, Chandini Singh, and Molin Zhong provided excellent research assistance. We are also grateful to Elizabeth Warren for facilitating access to the bankruptcy data and to the Horowitz Foundation and a Warburg grant from the Harvard Economics Department for financial support.

[Journal of Law and Economics, vol. 62 (August 2019)]

(c) 2019 by The University of Chicago. All rights reserved. 0022-2186/2019/6203-0016\$10.00 
and the causes of personal bankruptcy. We use an administrative panel data set from a lender and a discontinuity in the lender's underwriting rule to study the impact of payday loans on bankruptcy filings. The administrative panel includes information about the timing, size, and locations of applications as well as demographics for 145,000 applicants. Individual identifiers in the administrative data permit matching to bankruptcy petitions that are available from the Public Access to Court Electronic Records (PACER) database.

An institutional feature of the lender's underwriting process then allows statistical identification of the impact of payday loans on bankruptcy using a regression-discontinuity analysis. Payday loan applications are approved if the applicant's credit score exceeds a fixed threshold. Regression-discontinuity analyses rely on unobservable characteristics not changing discontinuously at the threshold. ${ }^{1}$ With this standard identifying assumption, differences in bankruptcy rates between barely approved and barely rejected applicants can be attributed to the causal impact of payday loan access. ${ }^{2}$

Our estimates answer the paper's title question affirmatively: yes, access to payday loans causes a significant increase in personal bankruptcy rates. The benchmark point estimate corresponds to a near doubling of the annual bankruptcy rate, with other specifications ranging between increases of 21 and 185 percent. Regression-discontinuity results can sometimes be fragile, so we show exactly how our findings depend on implementation choices, demonstrating robustness and allowing readers to focus on their preferred specifications for quantitative takeaways.

Even at the low end of the estimate range, the magnitudes we find are striking: payday loan principals average about $\$ 300$, but access has an economically significant effect on bankruptcy, a cumulative financial outcome. We therefore view the remainder of the paper, which complements the main bankruptcy impact analysis by extensively evaluating a series of possible mechanisms, as a second essential contribution. This investigation of mechanisms also contextualizes the paper within the literature on the determinants of bankruptcy.

A variety of forces have been implicated as drivers of bankruptcy-filing rates, including the pecuniary benefits of debt discharge (Fay, Hurst, and White 2002), stigma (Gross and Souleles 2002), the expansion of credit card indebtedness (Domowitz and Sartain 1999; White 2007), adverse health and medical expense shocks (Himmelstein et al. 2009; Morrison et al. 2013), and the ability to pay filing costs (Mann and Porter 2010; Gross, Notowidigdo, and Wang 2014). We find evidence for a complementary force, which to our knowledge is novel in this literature: payday loans increase bankruptcy rates by worsening borrowers' cash flow positions.

\footnotetext{
${ }^{1}$ For econometric foundations of the regression-discontinuity approach, see Thistlethwaite and Campbell (1960), Hahn, Todd, and Van der Klaauw (2001), Porter (2003), and McCrary (2008). Many modern applications stem from Angrist and Lavy (1999). Imbens and Lemieux (2008) provide a practical guide.

${ }^{2}$ For convenience, we refer to approval of one's first payday loan application, conditional on applying, as the effect of payday loan access.
} 
Using individual-level variation ${ }^{3}$ (rather than the typical changes in state regulatory environments or zip-code-level and county-level shocks), we are able to contribute new evidence on the effects of high-interest credit. ${ }^{4}$ Other analyses of the effects of payday loan access include Lefgren and McIntyre (2009), Zinman (2010), Melzer (2011), Morse (2011), Morgan, Strain, and Seblani (2012), Carrell and Zinman (2014), Bhutta (2014), Bhutta, Skiba, and Tobacman (2015), and Carter and Skimmyhorn (2017). Caskey (2012) reviews the mixed collection of findings in this literature, and we contextualize our contribution in Section 6.1. This unique, large-scale, matched database and our individual-level identification strategy allow us to explore the microeconomic channels through which credit affects consumers, which complements the rich literature that identifies marketlevel impacts of credit.

It is sometimes suggested that the central policy question is whether payday loans suck borrowers into a downward spiral of financial distress. The answer we come to in this paper is nuanced and involves a reframing of the question. We find the empirical evidence compelling that payday loan access causes personal bankruptcy rates to increase. The mechanism supported most strongly is that the bankruptcies could arise because of the cash flow burden of pressing payday finance charges. Additional theoretical work, beyond the scope of this paper, should investigate whether this household cash flow mechanism is or is not consistent with a downward-spiral view. Beyond these considerations, it could be the case that the bankruptcy filings benefit the filers, providing a fresh start following their longstanding financial distress. Bankruptcy filings also cause other debt to become delinquent, which distorts equilibrium interest rates for those who are not payday borrowers. Instead of further discussing a possible downward spiral, we therefore attempt in Section 6.2 to seriously analyze the private and social costs and benefits of bankruptcy filings.

The remainder of the paper is organized as follows. In Section 2 we provide additional background on payday loans and introduce the administrative data. Section 3 describes our estimation strategy, focusing on the credit-score discontinuity. We present our main empirical results and robustness checks in Section 4 and discuss mechanisms driving those results in Section 5. Section 6 examines the implications and relates our work to previous literature, and Section 7 concludes.

\footnotetext{
${ }^{3}$ Among the vast literature in economics on borrowing and credit, there is relatively little empirical research on the causal impact of individual-level random variation in the ability to borrow money, as in this paper. Excellent exceptions are Ausubel (1999) and Gross and Souleles (2002) on credit cards and Karlan and Zinman $(2008,2009,2010)$ on South African consumer credit.

${ }^{4}$ Payday loans are often described as a form of "fringe banking" (Caskey 1994). Like checkcashing services and pawnshops, payday lenders provide alternatives to traditional banks. Caskey $(1991,1994,2001,2005,2012)$ examines fringe banking in great detail, Flannery and Samolyk (2005) analyze the profitability of the payday-lending industry, Elliehausen and Lawrence (2001) conduct surveys of payday borrowers, and Stegman and Faris (2003) review the payday loan industry's business practices.
} 


\section{Context and Data}

Administrative data were supplied for this project by a provider of financial services that offers payday loans. To apply for a payday loan at this company, individuals fill out paper applications and present their most recent pay stubs, checking account statements, utility or phone bills, and state-issued photo identification cards. The lender uses applicants' pay stubs to infer the dates of their next paydays and assign loan due dates. Loans are collateralized only with personal checks dated on borrowers' upcoming paydays. ${ }^{5}$ Finance charges equal 18 percent of the loan's principal. The 2-week loan term that is most common implies an APR of 18 percent $\times 26=468$ percent, since people who are paid biweekly receive 26 paychecks per year. ${ }^{6}$

We study the universe of individuals whose first loan application at the company occurred at an outlet in Texas between September 2000 (when the firm entered that market) and August 2004. This includes about 1 million loan applications from 145,159 individuals. Table 1 presents demographic and background characteristics of this population and summary information about their applications and loans. ${ }^{7}$ There is variation in the availability of the background characteristics, mostly because of changes over time in the data collection and data retention practices by the lender. ${ }^{8}$

Overall, the available observables align with the broader population of payday borrowers (see, for example, Elliehausen and Lawrence 2001). Table 1 also reports summary statistics for a subgroup of 31,892 applicants on which we focus in some of the empirical analysis whose credit score is within .5 standard deviations of the passing payday loan credit-score threshold. We describe this threshold in detail in Section 3.1.

Summary statistics for the bankruptcy data are presented in Tables 2 and 3. Personal bankruptcy petitions are in the public record and were downloaded from PACER. We obtained the universe of 556,767 personal bankruptcy filings

\footnotetext{
${ }^{5}$ The longstanding practice of some employers providing advances against upcoming paychecks is distinct from the topic studied here: payday lenders do not directly garnish future paychecks to obtain loan repayment.

${ }^{6}$ Payday lenders typically do not allow interest to compound, but an alternative measure of the annualized cost of liquidity from biweekly payday loans is $100 \times\left(1.18^{26}-1\right)=7,295$ percent.

${ }^{7}$ All dollar values are deflated with the Consumer Price Index for All Urban Consumers to January 2002 dollars. We replace the top and bottom .1 percent of the distributions of checking account balance and take-home pay with signifiers for missing data. We also replace age with a signifier for missing data if it is less than 18 .

${ }^{8}$ For the data extract we use, the company stopped collecting some work-related variables in August 2003, namely, job tenure, pay frequency, and income. It had, in December 2002, stopped collecting information on wage garnishment and homeownership. This means that only a few observations (less than 2 percent) are missing those control variables for reasons that are uncorrelated with the time effects that we control for in all the paper's specifications. The firm that provided the data also offers pawn loans. Data on race and sex are collected incidentally since all of the information on drivers' licenses is recorded in accordance with pawnbroking underwriting rules. Those variables are therefore available in our data only for people who had pawned an item at the company prior to their first payday loan application. Thus, missing values for race and sex are perfectly correlated with a dummy for not having previously taken a pawn loan at this company. We include that dummy variable in all specifications below.
} 


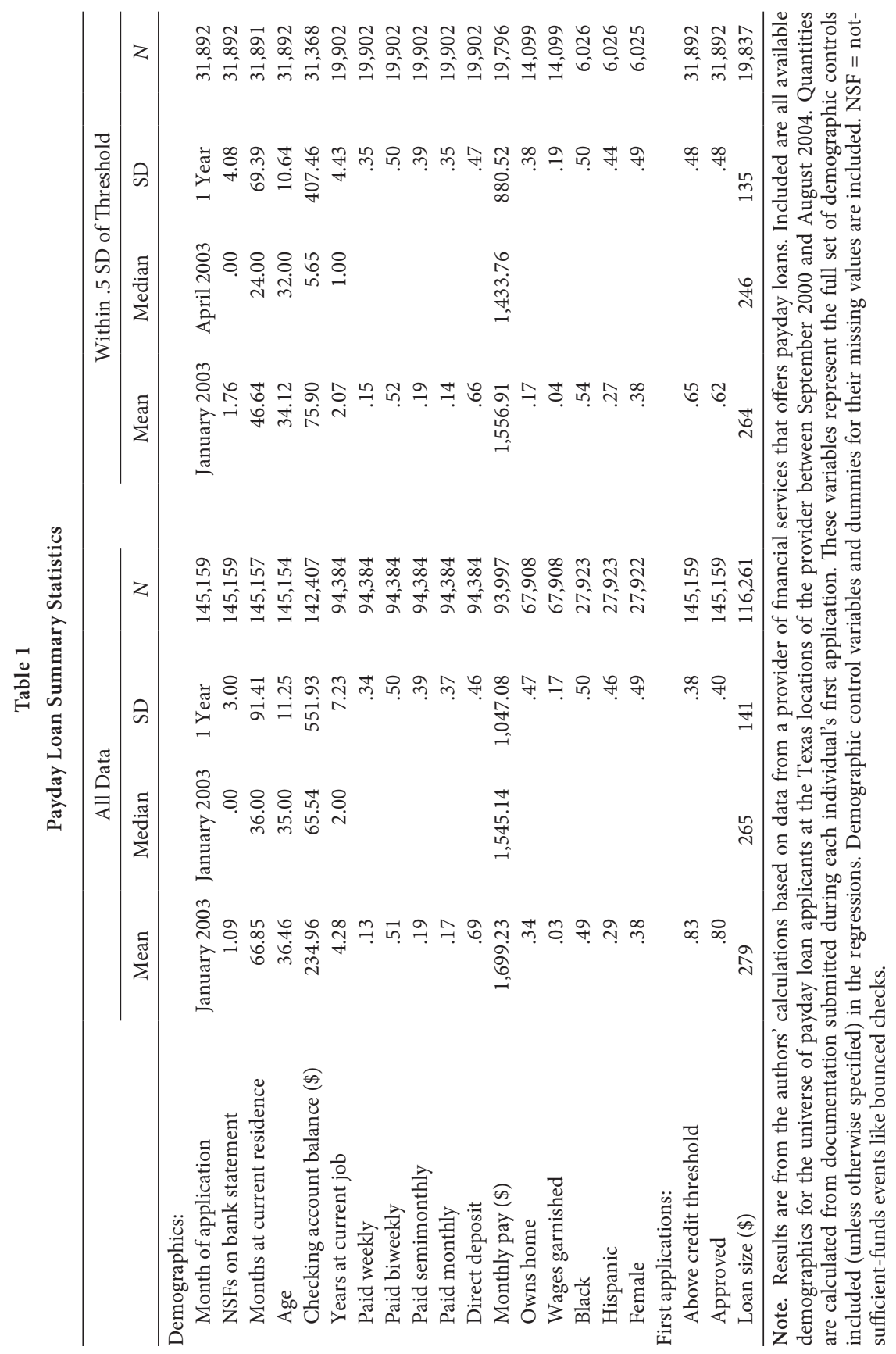

This content downloaded from 129.059.122.098 on February 12, 2020 11:06:05 AM All use subject to University of Chicago Press Terms and Conditions (http://www.journals.uchicago.edu/t-and-c). 
Table 2

Texas Bankruptcy Totals, 2000-2006

\begin{tabular}{lcccc}
\hline & Bankruptcies & $\begin{array}{c}\text { Annual Personal } \\
\text { Bankruptcy Rate }\end{array}$ & $\begin{array}{c}\text { Filers Who } \\
\text { Ever Applied }\end{array}$ & $\begin{array}{c}\text { Petitions per } \\
\text { Applicant } \\
\text { per Year }\end{array}$ \\
\hline Chapter 7 & 311,864 & .205 & 3,903 & .384 \\
Chapter 13 & 244,903 & .161 & 9,637 & .948 \\
All & 556,767 & .366 & 13,540 & 1.333 \\
\hline
\end{tabular}

Note. The data are from the Public Access to Court Electronic Records (PACER) database. The Texas-wide personal bankruptcy rate is calculated using PACER bankruptcy data and population data from the Census Bureau. Bankruptcy rates among payday loan applicants are calculated by matching administrative data from a payday lender to individual bankruptcy filings in PACER, using first names, last names, zip codes, and the final four digits of social security numbers.

Table 3

Payday Loan Applicants' Bankruptcy Rates

\begin{tabular}{|c|c|c|c|c|c|c|}
\hline & \multicolumn{2}{|c|}{ All Credit Scores } & \multicolumn{2}{|c|}{$\begin{array}{c}\text { Within .5 SD of } \\
\text { Approval Threshold }\end{array}$} & \multicolumn{2}{|c|}{$\begin{array}{l}\text { Within } .05 \text { SD of } \\
\text { Approval Threshold }\end{array}$} \\
\hline & Below & Above & Below & Above & Below & Above \\
\hline \multicolumn{7}{|l|}{$\begin{array}{l}\text { Within } 1 \text { year after first } \\
\text { application: }\end{array}$} \\
\hline Chapter 7 & .41 & .69 & .37 & .51 & .36 & .41 \\
\hline Chapter 13 & 1.62 & 1.94 & 1.49 & 1.55 & 1.46 & 2.91 \\
\hline Chapter 13 and dismissed & 1.03 & 1.07 & .91 & .98 & .95 & 1.74 \\
\hline All & 2.03 & 2.63 & 1.86 & 2.06 & 1.82 & 3.32 \\
\hline \multicolumn{7}{|l|}{$\begin{array}{l}\text { Within } 2 \text { years after first } \\
\text { application: }\end{array}$} \\
\hline Chapter 7 & .60 & 1.17 & .55 & .83 & .44 & .82 \\
\hline Chapter 13 & 2.53 & 3.31 & 2.30 & 2.55 & 2.63 & 4.14 \\
\hline Chapter 13 and dismissed & 1.51 & 1.71 & 1.31 & 1.56 & 1.46 & 2.20 \\
\hline All & 3.13 & 4.48 & 2.84 & 3.38 & 3.07 & 4.95 \\
\hline Applicants & 25,305 & 119,854 & 11,320 & 20,572 & 1,370 & 1,958 \\
\hline$N$ & 145,159 & & 31,892 & & 3,328 & \\
\hline
\end{tabular}

Note. Bankruptcy rates are calculated by matching administrative data from a payday lender to individual bankruptcy filings in PACER, using first names, last names, zip codes, and the final four digits of social security numbers. Two-year rates are not annualized.

in the four US bankruptcy courts in Texas from 2000 through 2006. ${ }^{9}$ These bankruptcy data include the date of filing, the chapter $\left(7\right.$ or 13), ${ }^{10}$ the disposition of

${ }^{9}$ The Bankruptcy Abuse Prevention and Consumer Protection Act of 2005 (BAPCPA) modified US bankruptcy law substantially. It was enacted on April 20, 2005, and became effective 6 months later. We lack statistical power to draw clear conclusions about the interaction of BAPCPA and payday loan access. Most applicants for payday loans we study have incomes low enough that they meet the (more stringent) post-BAPCPA means-test criterion for a Chapter 7 filing.

${ }^{10}$ Filing under Chapter 7 generally results in a full discharge of debt obligations. Filing under Chapter 13 entails a reorganization of debts. Below we discuss in more detail the important differences. 
the bankruptcy case (generally, dismissal or discharge of debts), ${ }^{11}$ and individual identifiers that permit linkage to the payday loan data.

Table 2 shows an individual bankruptcy rate (as a fraction of population) for Texas of .366 percent per year. ${ }^{12}$ We identify debtors in the PACER bankruptcy data as payday loan applicants if the following variables in the two data sets match exactly: first name, last name, zip code of home residence, and last four digits of the social security number. By these criteria, 13,540 of the 145,519 applicants filed for personal bankruptcy during the bankruptcy sample period. Thus, the annual bankruptcy rate among payday applicants is $13,540 /(145,519 \times 7)=1.33$ percent per year, more than 3.5 times the overall annual rate in Texas from 2000 to 2006. This average difference is also displayed over time in Online Appendix Figure OA1.

Table 3 provides summary information about the fraction of applicants above and below the credit threshold who subsequently filed for bankruptcy. These averages imply that people above the credit-score threshold are more likely to file. This is true for the full sample and for samples of .5 and .05 standard deviations around the threshold. These differences are suggestive of a relationship between payday lending and bankruptcy. For more thorough analysis, next we turn to regressions that exploit the discontinuous access to payday loans near the creditscore threshold.

\section{Identification and Empirical Strategy}

\subsection{The Credit-Score Regression Discontinuity}

Access to payday loans depends on a credit score calculated at the time of the loan application by the third-party credit bureau Teletrack. ${ }^{13}$ During our observation period, the lender maintained a fairly strict threshold rule for loan approvals. Among first-time applicants with scores below the threshold, 99.6 percent were rejected, while 96.9 percent of first-time applicants scoring above the threshold were approved. The threshold rule did change during our sample period. We discuss the effects of this change in Section 4.3. In most of the empirical analysis, we pool the data and use the variable Credit Score, which equals the raw Teletrack score minus the approval threshold that was in force at the time of the applica-

\footnotetext{
${ }^{11}$ We focus primarily on bankruptcy petitions and secondarily on whether debt was eventually discharged; filing is an indicator of financial distress (Fay, Hurst, and White 2002). Bankruptcy law precludes creditors from contacting debtors once a petition is filed, so debtors may file to protect themselves from creditors even if their debts are unlikely to be discharged. Hereafter, we use the terms "petition" and "filing" interchangeably.

${ }^{12}$ Population data are from Census Bureau, Table 1: Annual Estimates of the Population for the United States and States, and for Puerto Rico: April 1, 2000 to July 1, 2005 (https://www2.census .gov/programs-surveys/popest/tables/2000-2005/state/totals/nst-est2005-01.xls).

${ }_{13}$ The credit-scoring formula is proprietary, but in personal communications with Teletrack personnel we were told these scores differ from Fair Isaac Corporation (FICO) scores in that they depend on a shorter history of behavior and focus on borrowing in the subprime market. Though Teletrack serves major payday lenders, the lenders establish their own criteria for approving loan applications. In other work (Skiba and Tobacman 2008; Agarwal, Skiba, and Tobacman 2009), we discuss more details of the credit-scoring process in the context of the profitability of payday lenders.
} 


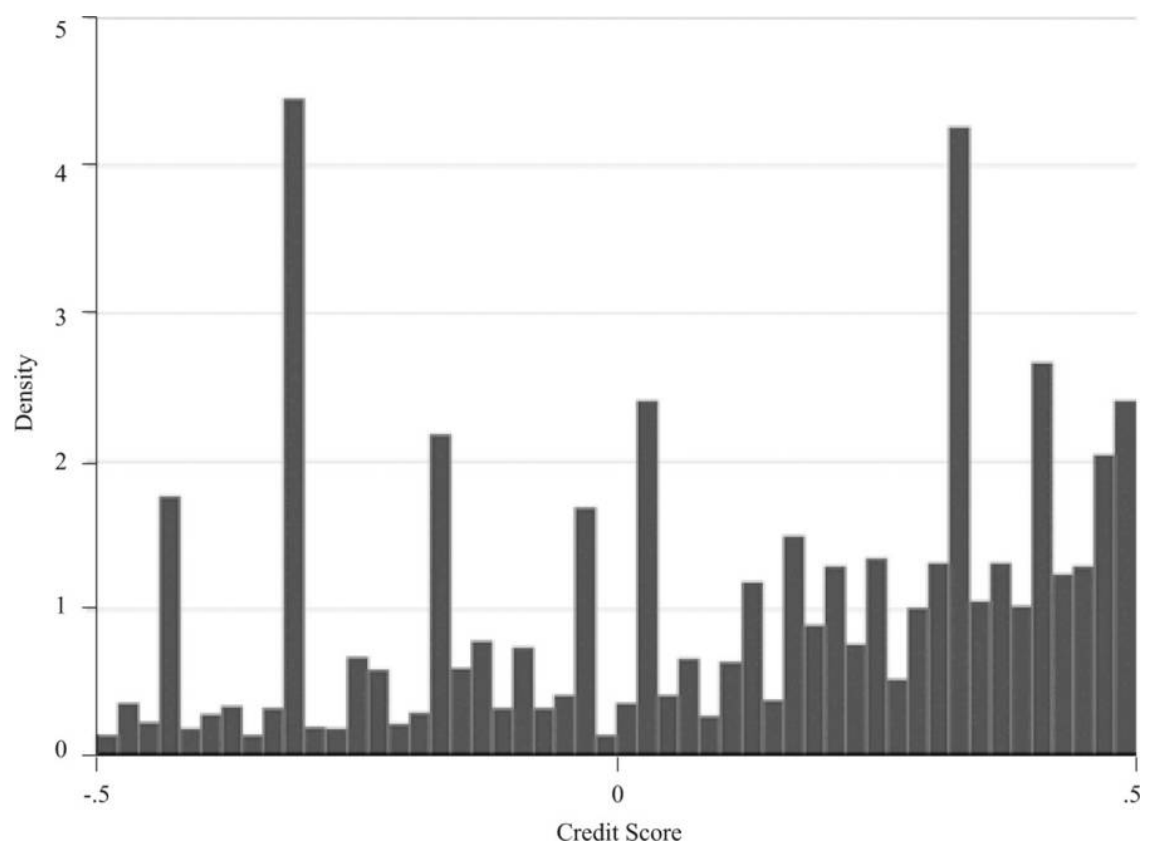

Figure 1. Distribution of Teletrack scores

tion, normalized by the standard deviation of raw scores during the corresponding period. Figure 1 displays a histogram of Credit Score, which indicates that there is discreteness in the distribution but no unusual bunching in proximity to the threshold.

Consistent with the company's stated policy, the credit score has a discontinuous effect on the probability that a payday loan application is approved. Figure 2 shows the probability of approval among first-time applicants (Approved) as a function of Credit Score. Two quartic polynomials, fit independently to the data on either side of the credit-score threshold, are superimposed on the graphs. We quantify this visually striking discontinuity by regressing Approved on an indicator for being above the threshold (AboveThr), controlling for a polynomial in Credit Score and background characteristics:

$$
\text { Approved }_{i}=\beta_{0}+\beta_{1} \text { AboveThr }_{i}+f\left(\text { Credit Score }_{i}\right)+\gamma \boldsymbol{X}_{i}^{\prime}+\delta M_{t i}^{\prime}+\varepsilon_{i},
$$

where $\boldsymbol{X}_{i}$ is a vector for borrower $i$ of all the demographic and background characteristics provided by the company and reported in Table 1 and $M_{t i}^{\prime}$ is a full set of dummies for the month-year of the first payday loan application, so $M_{t i}^{\prime}$ equals one if individual $i$ 's first application was in month $t$ and zero otherwise. A variety of choices can be made for the functional form of $f\left(\right.$ Credit Score $\left._{i}\right)$, and we adopt 


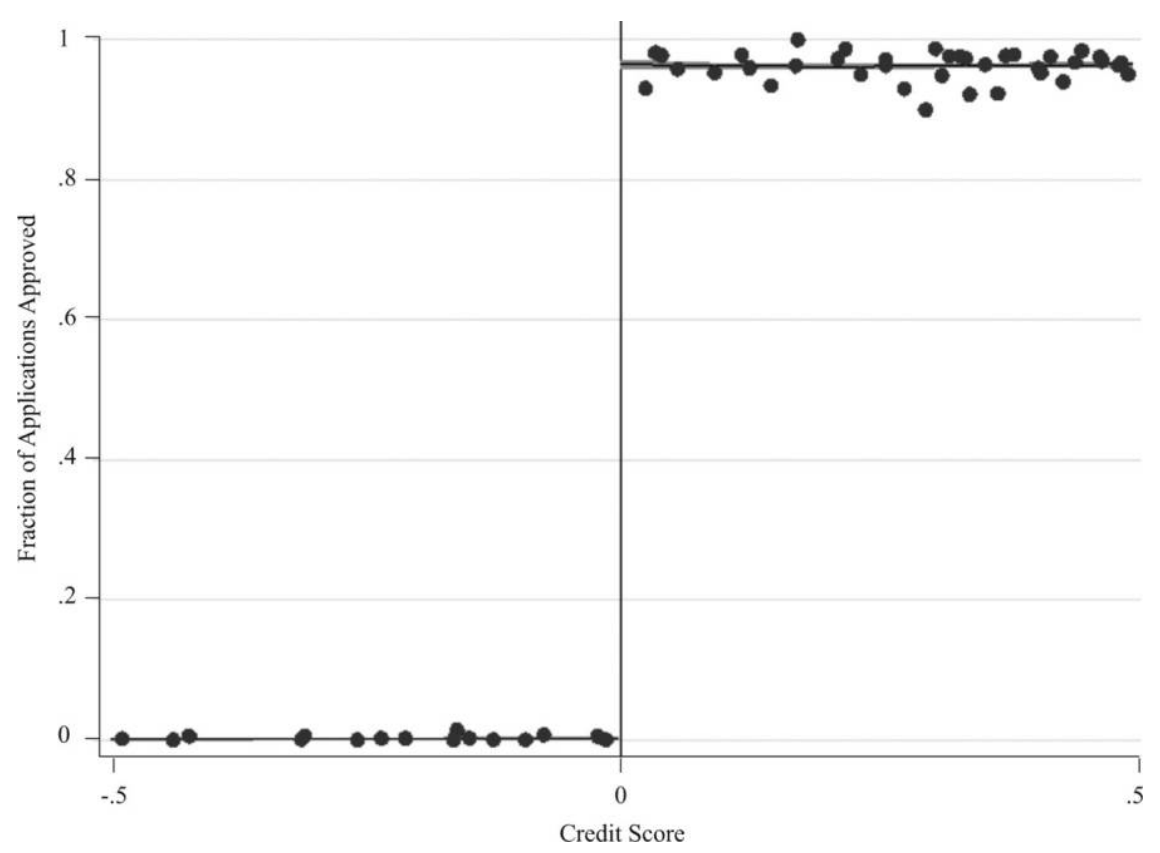

Figure 2. Probability of approval by credit score

an agnostic approach. Our benchmark specifications allow $f(\cdot)$ to be a quartic in Credit Score ${ }_{i}$ interacted with AboveThr ${ }_{i}{ }^{14}$

Informal default is common on payday loans: at this firm, over 30 percent of borrowers had a loan written off by the lender within a year of taking their first loans. In choosing the threshold for loan approval, the company therefore had incentives disconnected from bankruptcy-filing probabilities. To the extent that the company adjusted its threshold to decrease loan losses due to borrowers' bankruptcy filings, the bankruptcy rate should fall when crossing the threshold, which would bias our findings downward.

\subsection{Identification}

The identifying assumption for the regression-discontinuity design is that unobservables must not change discontinuously at the threshold. This assumption is not directly testable, but two main avenues are available for gaining insight about

${ }^{14}$ Table OA1 in the Online Appendix reports linear probability and probit estimates of equation (1) based on this specification. In every regression, the coefficient on AboveThr is highly significant and close to 1 . The $R^{2}$-value equals .90 when only AboveThr is included on the right-hand side. As the subsequent columns add a quartic in Credit Score fully interacted with AboveThr, the demographics listed above, and the dummies for month of first payday loan application, the coefficient on AboveThr hardly changes, and the $R^{2}$-value increases by only 1 percent. Results from probit equations (showing marginal effects) reveal the same pattern. 
it. The first avenue relates to observable characteristics. If observables do not change discontinuously at the threshold, that is neither necessary nor sufficient to guarantee that unobservables also do not, but it increases our confidence. Figure OA2 plots the 16 control variables from Table 1 versus Credit Score and indicates reasonable but imperfect balance. Table OA2 in the Online Appendix provides further information about balance across the threshold. It shows that the balance of the raw variables improves as the range around the threshold shrinks; it also shows estimates of the discontinuities using the same approach we use to estimate the bankruptcy effects of interest below.

Imbalances are most pronounced for age, checking account balance, and months at current residence, all of which are modestly higher above the credit score threshold. Manipulation of these types of covariates to get over the threshold would be problematic: applicants successful at this kind of manipulation could also be successful at navigating the bankruptcy-filing process, for example.

We view this type of manipulation as unlikely for the checking account balances, which are measured with bank statements, but possible with the (unverified) variable measuring months at current residence. Were borrowers to know the impact that this has on loan access, they might wait until a sufficient amount of time has elapsed to apply for a loan.

Encouragingly, there is no difference in the discontinuity on the basis of whether people have multiple applications on the same day as their first application (some people reapply immediately after being rejected). It does not appear that applicants and the lender are trying to adjust underwriting variables in real time to gain approval.

Reassuringly for our strategy, the particular directions of imbalances we observe across the threshold in Table OA2 and Figure OA2 usually would induce omitted-variables bias that would go against our bankruptcy findings below. For example, above-threshold applicants have slightly higher checking account balances and residential stability.

Moreover, institutional features of the underwriting process increase our confidence in the exogeneity of AboveThr $r_{i}$ conditional on $f\left(\right.$ Credit Score $\left._{i}\right)$ for firsttime applicants. First, during the application process, the payday loan company's employee submits information about the applicant electronically to the company's central servers, which in turn send a query to Teletrack. Within minutes, a notification of whether the application was approved or declined is returned to the employee. Neither applicants nor the employees in the store are informed of the applicants' scores or the passing credit-score threshold. Second, Teletrack uses additional information from other lenders, which is not available to this lender's employees, to compute the score: an ordinary least squares (OLS) regression of the Teletrack scores of first-time payday loan applicants on the demographic and background variables in Table 1, including a full set of monthyear dummies, yields an $R^{2}$-value of just .304. This process limits the capacity of applicants and clerks to decisively manipulate applications, which increases our confidence that AboveThr affects an individual's future choices only insofar as it 
affects application approval. In light of these considerations, and following best practices for regression-discontinuity implementations, we control for all of the available covariates and proceed.

\subsection{Regression-Discontinuity Specifications}

Using the credit-score discontinuity described in Section 3.2, we estimate the effect of payday loan approval on bankruptcy at various horizons (from 1 day to 27 months) after the first payday loan application. ${ }^{15}$ Our main outcome of in-

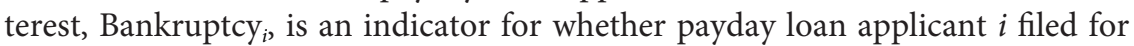
bankruptcy within 1 or 2 years of his or her first payday loan application. We consider several specifications, the first of which is an OLS specification:

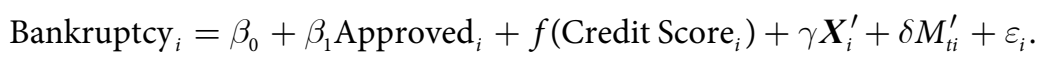

Our main specification is a reduced-form equation:

$$
\text { Bankruptcy }_{i}=\beta_{0}+\beta_{1} \text { AboveThr }_{i}+f\left(\text { Credit Score }_{i}\right)+\gamma \boldsymbol{X}_{i}^{\prime}+\delta M_{t i}^{\prime}+\varepsilon_{i} .
$$

Finally, we report instrumental-variables regressions, instrumenting for Approved in equation (2) with AboveThr. ${ }^{16}$

Analyses identified from discontinuities generally involve a trade-off as more and more data are included around the discontinuity (that is, as the bandwidth increases). The additional data reduce sampling noise but potentially introduce bias as weight is placed on observations where unobservables may be correlated with the outcome. ${ }^{17}$

We take an agnostic perspective about how to proceed in light of this trade-off, demonstrating robustness to a variety of choices. First, we restrict to subsets of the data, narrowing to \pm .5 and \pm .05 standard deviations around the credit-score threshold. These bandwidth restrictions result in samples with 31,892 and 3,328 applicants, respectively. Second, we implement optimal bandwidth estimates fol-

\footnotetext{
15 The last payday loan applications in the administrative data set occur in August 2004, and we study bankruptcies through the end of 2006, so at least 27 months of outcome data are available for all applicants.

${ }_{16}$ Throughout the paper, we focus on identification from first applications. In principle, more power would be available if our first stage included all applications. However, there is more slippage between AboveThr and application approval after the first loan application: the lender is more likely to have a history for a repeat applicant that informs its approval choice. In addition, the regression results reported above indicate that we already have considerable power in the first stage, and using all applications would require correcting for intra-applicant correlation structure in the effect of AboveThr on application approval and the effect of approval on the outcome variables of interest. In principle, it would be possible to replicate the instrumental-variables regressions using a new endogenous variable, an indicator for whether an individual has ever had an application approved.

${ }^{17}$ The starkness of the trade-off is highlighted in Table OA3. Suppose that instead of studying the effect of payday loans on bankruptcy using the discontinuity available in this field environment, we could run an experiment that randomly assigned payday-loan access. Table OA3 reports the numbers of observations necessary to have the specified probability of detecting various effect sizes at a 95 percent confidence level. For example, if the expected effect is an increase in the bankruptcy rate from 1.5 percent to 2 percent, then for 90 percent power almost exactly the number of observations that we have with a .5 -standard-deviation bandwidth would be required.
} 
lowing Calonico, Cattaneo, and Titiunik (2014a, 2014b) and Imbens and Kalyanaraman (2012). Third, we show how the direction and statistical significance of our findings vary for any bandwidth.

\section{Results}

\subsection{Descriptive Findings}

Figures 3, 4, and 5 show how the 2-year bankruptcy rate varies with Credit Score in six ways that all suggest that payday loan access increases personal bankruptcy rates. Figure $3 A$ reports the raw bankruptcy rates, where each dot corresponds to one of 40 bins. The averages to the left and right of the threshold are 2.84 percent and 3.38 percent, respectively, as in Table 3 . Smoothed polynomial fits are also plotted with 95 percent confidence intervals. Figure $3 B$ replicates Figure $3 A$, except that we use the residuals from a regression of the Bankruptcy indicator on the control variables and the month dummies.

Since filing a bankruptcy petition is such a rare outcome, averaging only 31,892 $\times 3$ percent $/ 40=24$ events per bin, some volatility is evident in Figure $3 \mathrm{~A}$ and $3 B$. Figure 4 , before plotting, takes the cumulative sum of bankruptcy events $(4 A)$ and residuals $(4 B)$ from left to right and plots that cumulative sum against Credit Score. For a binary outcome variable like a bankruptcy indicator, a regression discontinuity in levels corresponds to a regression kink in the cumulative sum, so an effect of payday loan access on bankruptcy is present if the slope differs across the threshold in Figure 4.

Figure 5 again shows the cumulative sums of bankruptcy events and residuals, but with the horizontal axis as the applicant's Credit Score rank. Figure $5 \mathrm{~A}$ and $5 B$ show all of the observations below the threshold and an equal number of observations above the threshold, respectively. Again, an effect of payday loan access on bankruptcy rates would appear as a change in slope at the threshold.

\subsection{Conventional Regression-Discontinuity Results}

Tables 2 and 3, along with Figures 3-5, suggest that payday loan access increases bankruptcy rates. We formalize and quantify first by estimating equations (2) and (3) in Table 4. Regressions report point estimates and standard errors of $\beta_{1}$ for bankruptcies at 1- and 2-year time horizons since the first loan application. Each point estimate in Table 4 is from a different regression. The outcome variables are multiplied by 100 , so the coefficients can be interpreted as the increase in bankruptcies in percentage points associated with unit increases in the independent variables.

Section 3 demonstrates that a large share of the variation in Approved can be explained by AboveThr, the indicator for whether the credit score is above the lender-defined threshold. To the extent that individual characteristics cause slippage between AboveThr and loan approval, correlation between those characteristics and propensity or ability to declare bankruptcy (for example, if loan ap- 

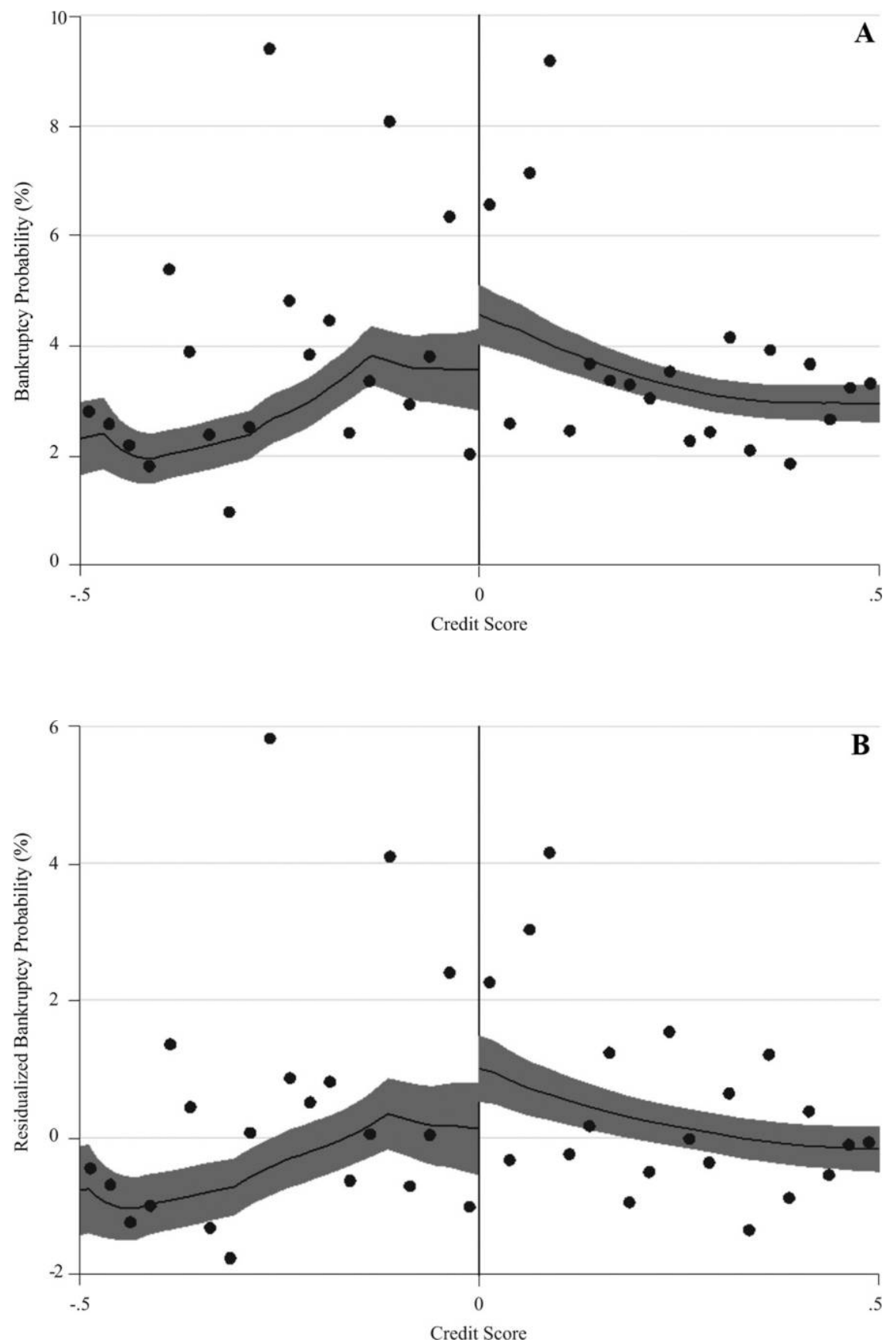

Figure 3. Probability of bankruptcy within 2 years. $A$, Raw bankruptcy rates; $B$, residualized bankruptcy rates.

This content downloaded from 129.059.122.098 on February 12, 2020 11:06:05 AM

All use subject to University of Chicago Press Terms and Conditions (http://www.journals.uchicago.edu/t-and-c). 

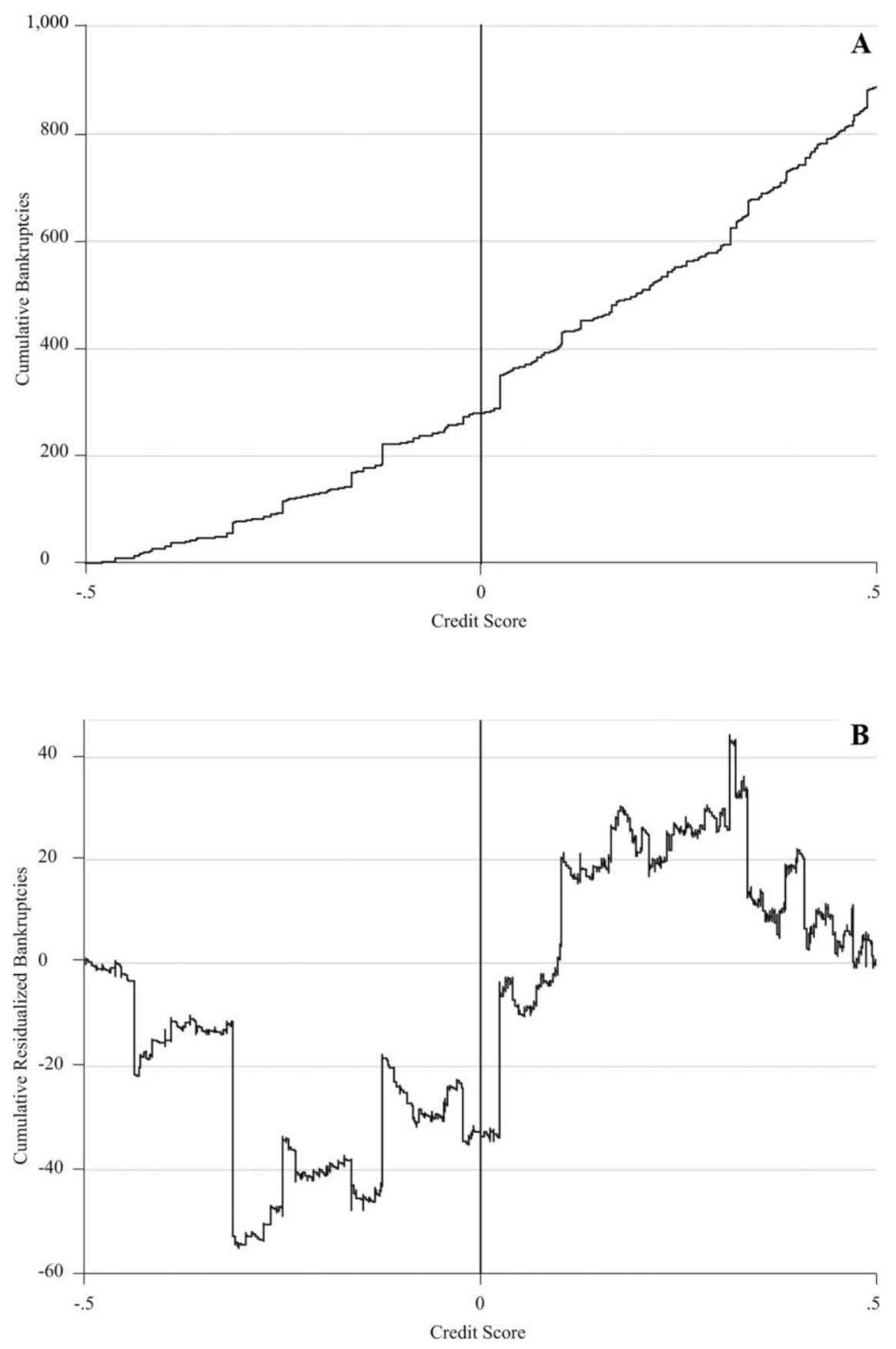

Figure 4. Cumulative bankruptcies within 2 years. $A$, Raw cumulative bankruptcies; $B$, residualized cumulative bankruptcies.

This content downloaded from 129.059.122.098 on February 12, 2020 11:06:05 AM All use subject to University of Chicago Press Terms and Conditions (http://www.journals.uchicago.edu/t-and-c). 

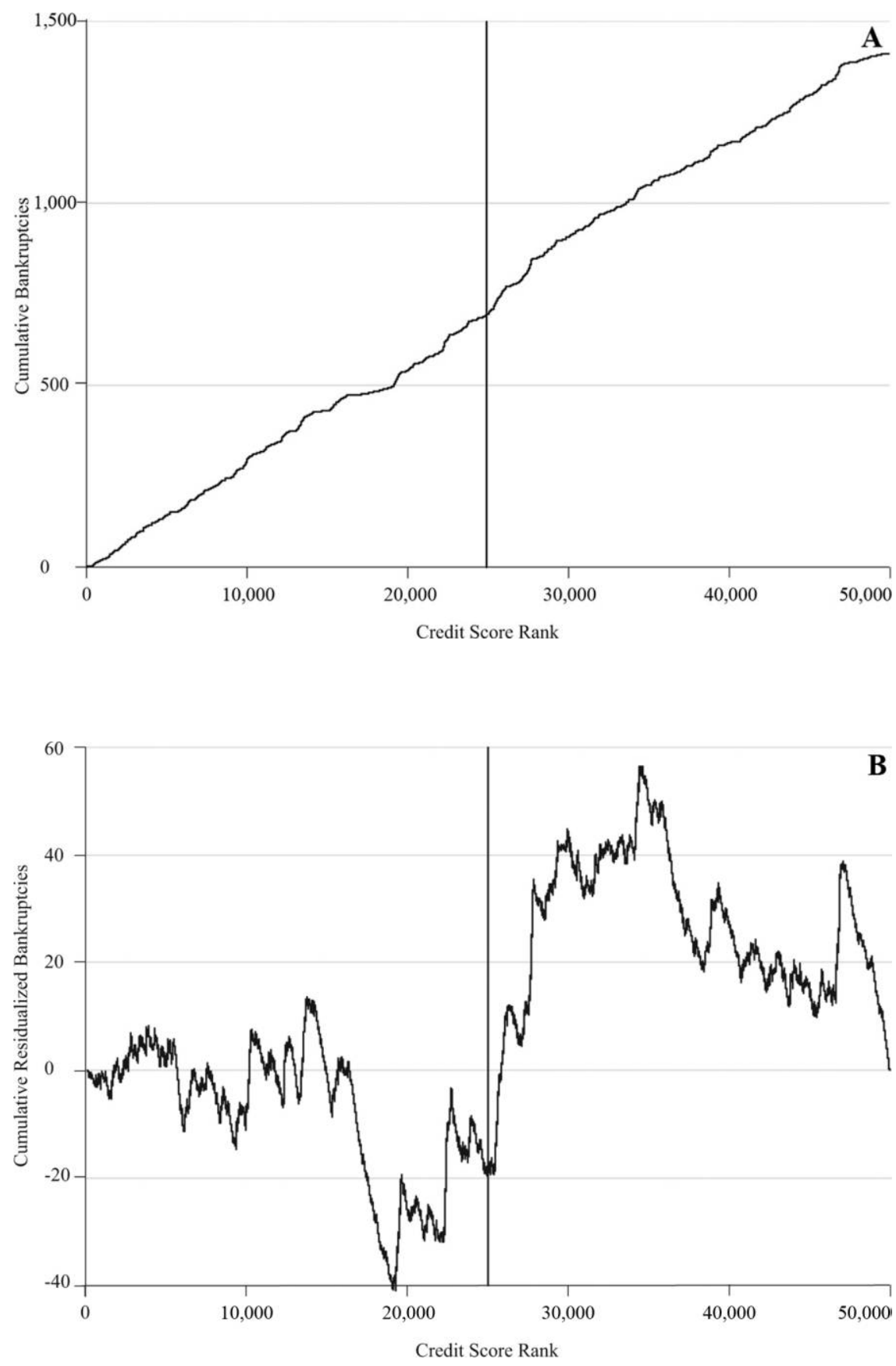

Figure 5. Cumulative bankruptcies within 2 years: ranked scores. $A$, Raw cumulative bankruptcies; $B$, residualized cumulative bankruptcies.

This content downloaded from 129.059.122.098 on February 12, 2020 11:06:05 AM All use subject to University of Chicago Press Terms and Conditions (http://www.journals.uchicago.edu/t-and-c). 


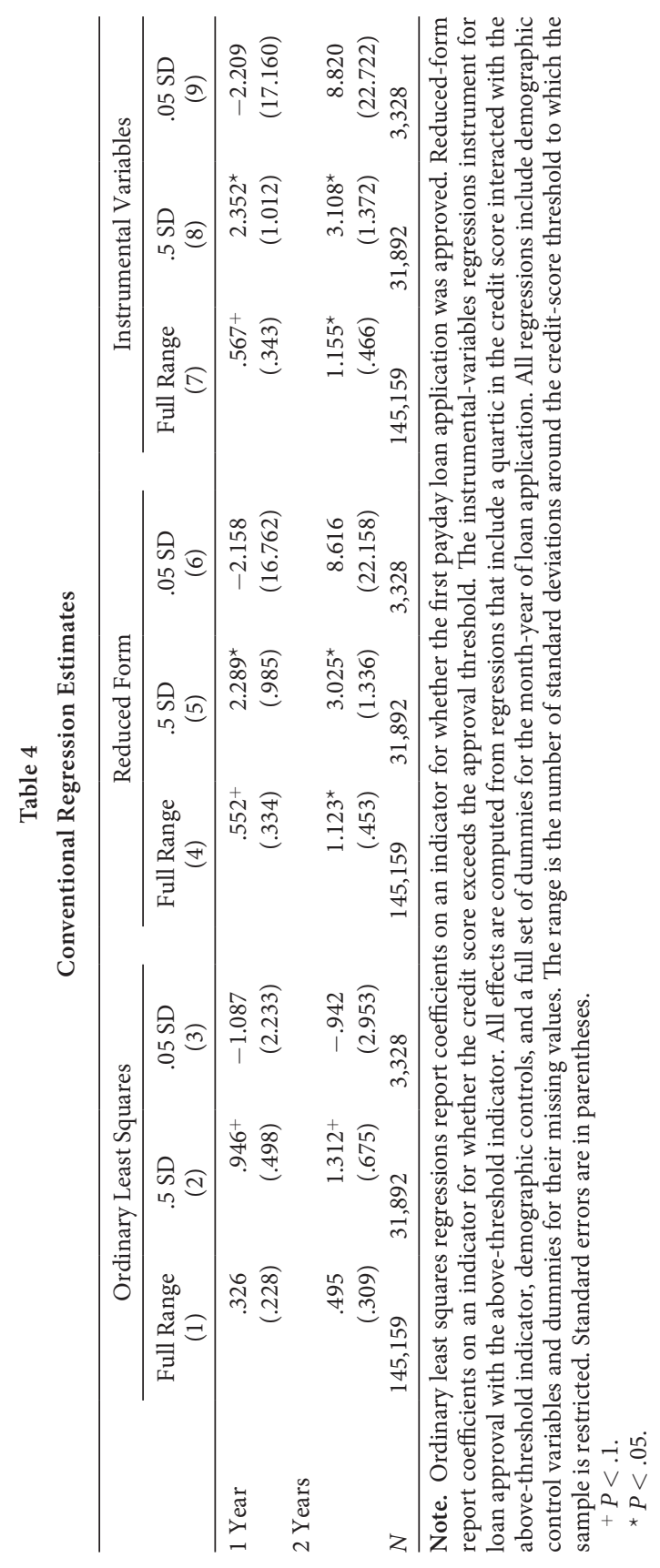

This content downloaded from 129.059.122.098 on February 12, 2020 11:06:05 AM All use subject to University of Chicago Press Terms and Conditions (http://www.journals.uchicago.edu/t-and-c). 
proval is correlated with resourcefulness in filling out paperwork, which is also necessary for completing a bankruptcy filing) could bias even the restricted-range OLS estimates. We can more cleanly estimate the causal impact of payday loan access on bankruptcy by putting AboveThr on the right-hand side, as in equation (3). Controlling for $f\left(\right.$ Credit Score), $\boldsymbol{X}_{i}$, and the month of application as well, we obtain the results in columns $4-6$ of Table $4 .{ }^{18}$

Table 4 also shows that the reduced-form effect of AboveThr on bankruptcies is significant at the 5 percent level for the .5 -standard-deviation sample. Having a credit score above the passing threshold increases bankruptcies by 2.289 percentage points over 1 year, more than a doubling of the baseline rate of 1.864 percent. Standard errors grow large when we restrict to .05 standard deviations on either side of the threshold.

In columns 7-9 we instrument for Approved with AboveThr. As we would expect given the tight relationship between Approved and AboveThr reported above, these regressions are nearly identical to the reduced-form values in magnitude and significance. Effects for bankruptcies 2 years after the first payday loan are generally larger than the 1-year effects, statistically and economically.

\subsection{Alternative Specifications}

In six important ways, this section evaluates the directional and quantitative robustness of our conclusions. First, in Table 5 we employ the optimal bandwidth approaches of Calonico, Cattaneo, and Titiunik (2014a, 2014b) and Imbens and Kalyanaraman (2012), which formally balance the increased precision from additional data with the possible introduction of correlation in unobservables. Optimal bandwidths implied by these procedures tend to be larger than the \pm .5-standard-deviation windows adopted above, which imply numbers of observations greater than 31,892. Coefficients from the optimal bandwidth specifications tend to be smaller in magnitude but more highly statistically significant than the conventional regressions in Section 4.2. Robust estimated effects on the 2 -year bankruptcy rate range from .690 to 1.858 percentage points and are generally significant at the 1 percent level.

Second, we consider alternative functional forms for $f(\cdot)$ and the error structure. Instead of a quartic in Credit Score ${ }_{i}$ interacted with AboveThr ${ }_{i}$, we try cubics, quadratics, and linear functions interacted with AboveThr ${ }_{i}$ and quartics, cubics, quadratics, and linear functions not interacted with AboveThr ${ }_{i}$. Relatedly, instead of linear probability models, we implement probit models. Most of the coefficients in these specifications, reported in the Tables OA5-OA8, go in the same direction and are similarly significant.

Third, we examine robustness with respect to the bandwidth and the functional form of $f\left(\right.$ Credit Score $\left._{i}\right)$ by plotting point estimates and confidence intervals as

\footnotetext{
${ }^{18}$ The full regression results for these three specifications may be found in Table OA4. Beyond our coefficient of interest, a few other covariates are of note. There are statistically significant and positive coefficients on homeownership, checking account balance, job tenure, and monthly pay.
} 


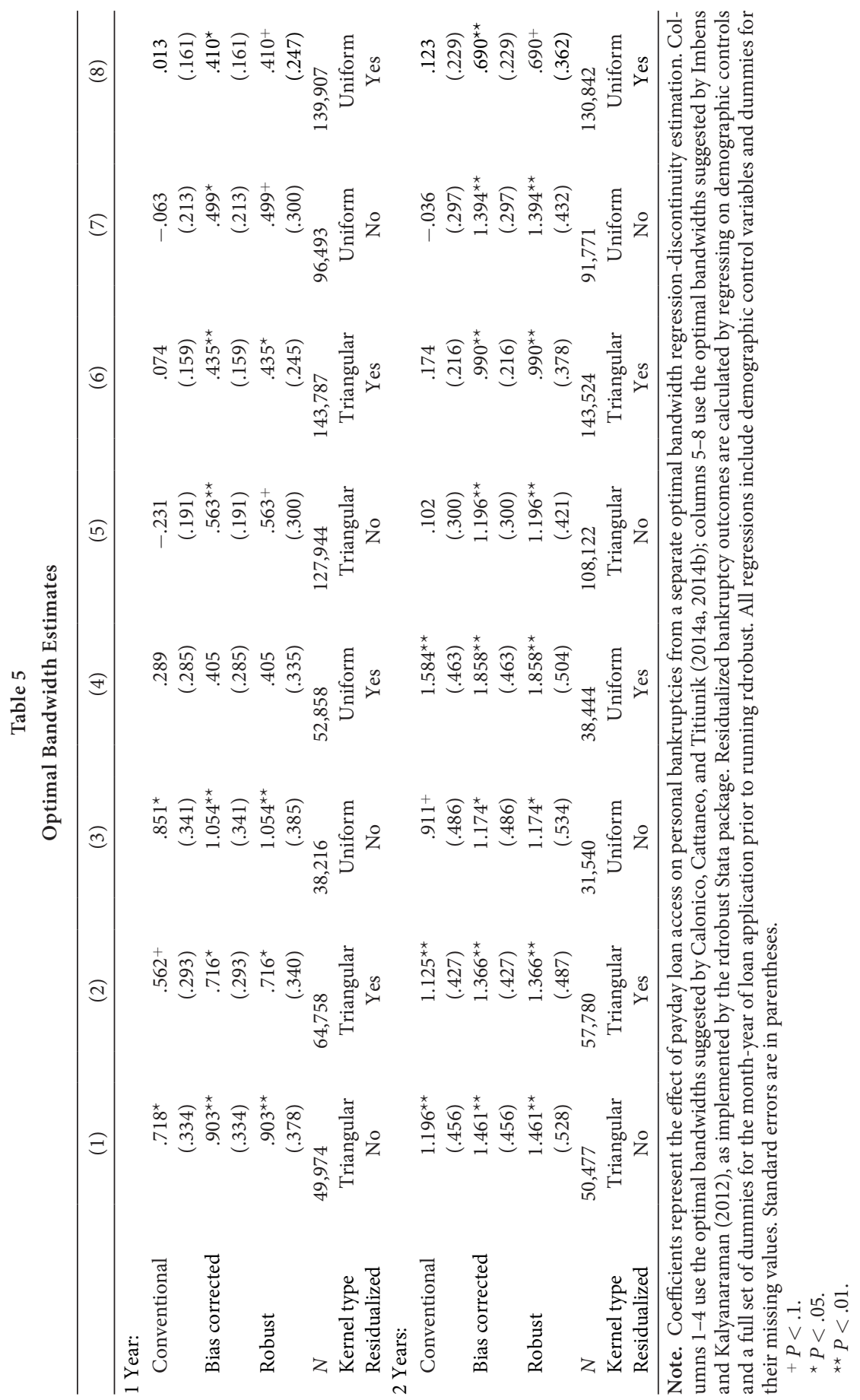

This content downloaded from 129.059.122.098 on February 12, 2020 11:06:05 AM All use subject to University of Chicago Press Terms and Conditions (http://www.journals.uchicago.edu/t-and-c). 
a function of the bandwidth in Figure $6 A$ (independent quartic functions) and $6 B$ (independent linear functions). The horizontal axis is the bandwidth in standard deviations around the credit-score approval threshold: smaller bandwidths restrict attention to smaller intervals around the threshold, so data points to the left are noisier than those to the right, which include more data. Figure $6 \mathrm{~A}$ and $6 B$ shows statistically significant effects for almost any interval around the threshold from \pm .4 standard deviations to \pm 1 standard deviation. To our knowledge, it is an innovation in the literature to demonstrate robustness of regressiondiscontinuity estimates in this fashion.

Fourth, in Figure 7 and associated Table OA9, we show the results of Cox proportional hazard regressions. These specifications incorporate information not only about whether a payday loan applicant files for bankruptcy but also about how quickly he or she does so after the payday loan application. Again, we find statistically and economically significant evidence that payday loan access increases bankruptcy-filing rates as shown by the difference in cumulative hazard rates for those above and below the passing credit-score threshold.

Fifth, to the extent possible, we examine heterogeneity across the credit-score distribution. The credit-scoring formula and the threshold for approval were adjusted at the lender's storefronts only once each during our period of observation. On November 12, 2002, the lender began receiving credit scores from Teletrack based on a new formula with a lower mean and variance. Exactly 3 months earlier, the company had reduced the approval threshold by two-thirds of a standard deviation. The resulting approval rates for applications prior to August 12, 2002, between August 12 and November 11, 2002, and from November 12, 2002, onward were 85.2 percent, 94.6 percent, and 79.1 percent, respectively. For applicants within .5 standard deviations of the threshold, the approval rates during the three periods were 82.7 percent, 79.0 percent, and 52.1 percent, respectively. About three-fifths of the available observations are from the period after November 12,2002 , because the lender's business was growing rapidly, so power is limited when estimating treatment effects without that period. Table OA10 shows that the results are less precise but statistically indistinguishable in each period when identified separately off these several points in the Credit Score distribution. ${ }^{19}$

Sixth, the results reported above rely on data from a single payday lender, though applicants rejected by that firm might be able to obtain payday loans elsewhere. This means that the estimates represent a lower bound on the true effect of payday loan access on bankruptcy. Qualitatively, we expect the size of the underestimate to be moderate for two reasons. First, during our sample period most major payday lenders used Teletrack to provide information about loan applicants. Each lender, however, chooses its own rule for approving loan applications (and may use a smoother decision rule), and we lack information about those

\footnotetext{
${ }^{19}$ Regardless of this demonstration of robustness, we agree with Karlan and Zinman (2010) that it is particularly valuable to study the effects of credit access on marginally approved borrowers since they are likely to be the first borrowers affected by changes in policy or lenders' choices.
} 

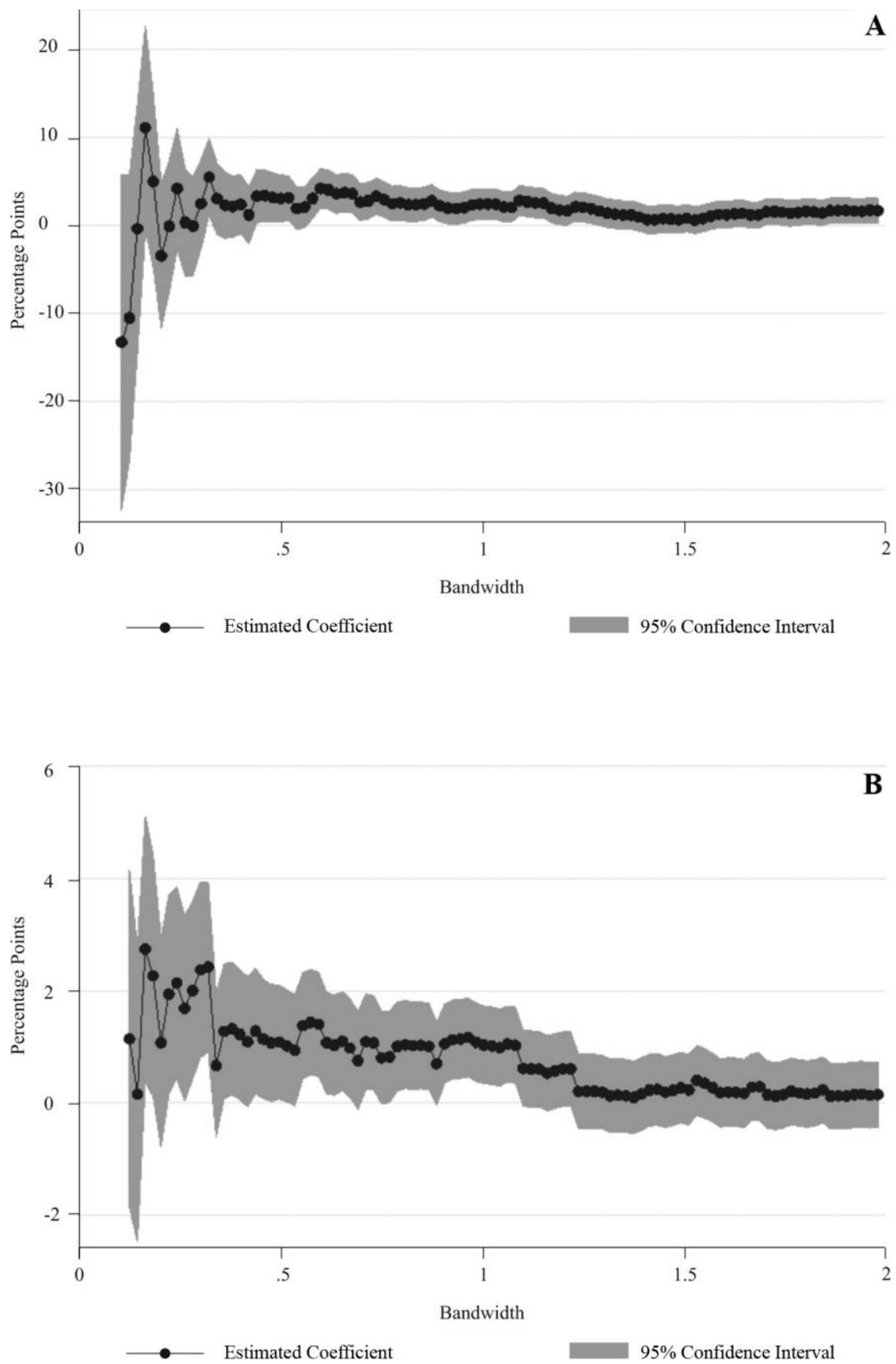

Figure 6. Effect of payday loans on bankruptcy as a function of bandwidths. $A$, Independent quartic function; $B$, independent linear function.

This content downloaded from 129.059.122.098 on February 12, 2020 11:06:05 AM All use subject to University of Chicago Press Terms and Conditions (http://www.journals.uchicago.edu/t-and-c). 


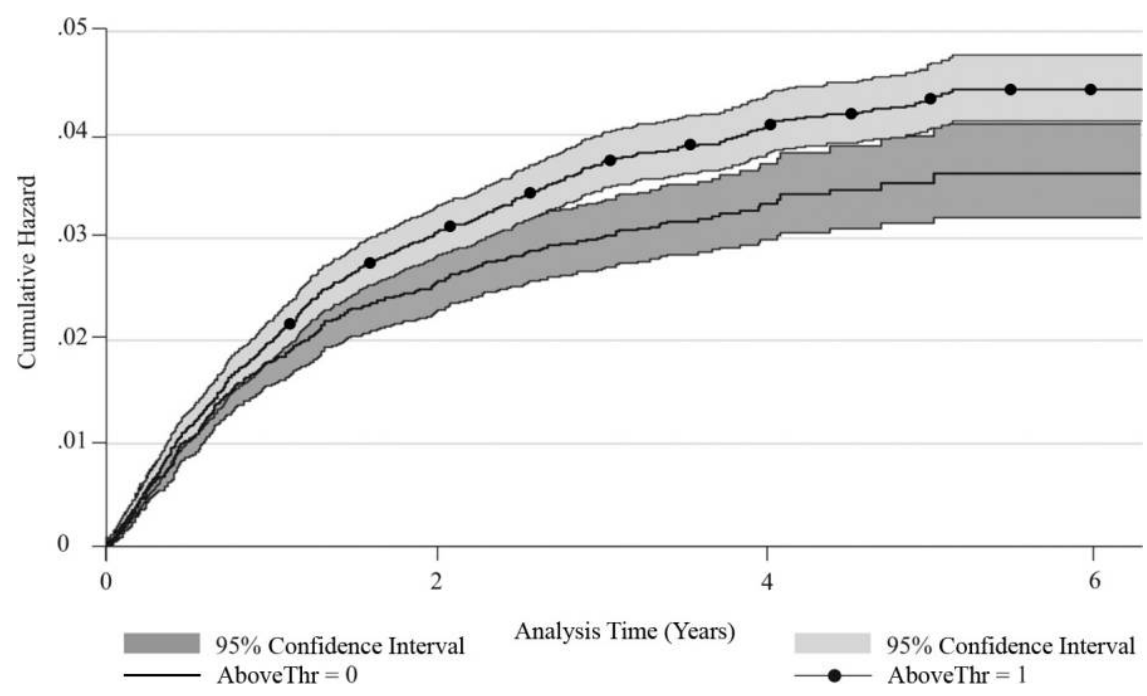

Figure 7. Effect of payday loan access on bankruptcy hazards

practices. ${ }^{20}$ If all lenders choose exactly the same threshold, our estimated coefficients will not reflect bias due to substitution opportunities. To the extent that the firms have comparable costs (Flannery and Samolyk 2005) and the industry is competitive (Skiba and Tobacman 2008), they would adopt identical thresholds in equilibrium. We also suspect that the underestimation of the effect of payday loan approval on bankruptcy is small because the company's loans remain attractive to rejected applicants. Of the 20 percent of applicants who were first rejected, 48 percent reapplied. Only 9 percent of reapplicants were approved, but those who were approved borrowed on average $\$ 2,485$ and paid $\$ 415$ in interest, similar to initially approved applicants who cumulatively borrowed $\$ 2,793$ and paid $\$ 477$ in interest.

Moving beyond those essentially speculative considerations, we attempt to quantify the possible bias due to outside borrowing opportunities. Table 6 reveals how the estimated treatment effects vary with proxies for the lender's zipcode-level market share. Local market share is proxied as follows. For each new applicant, we count the number of the company's stores visited by applicants residing in the new applicant's zip code. We divide this number by the Census Bureau's ZIP Codes Business Patterns' year-specific count of establishments with North American Industry Classification System codes 522291 and 522390 (Bhutta 2014). Columns 1 and 2 of Table 6 show that, as expected, the results attenuate when the lender has a low (below-median) market share, though the standard error on the point estimate in column 1 is large. The estimates in column 3

\footnotetext{
${ }^{20}$ Endogeneity of the approval decision rules does not matter for our estimates. The distribution of credit scores is smooth near the credit-score approval threshold, as shown in Figure 1.
} 
Table 6

Effects of Payday Loan Approval on Bankruptcy

Filings by Market Structure

\begin{tabular}{|c|c|c|c|}
\hline & $\begin{array}{l}\text { Low } \\
\text { Ratio } \\
\text { (1) }\end{array}$ & $\begin{array}{l}\text { High } \\
\text { Ratio } \\
\text { (2) }\end{array}$ & $\begin{array}{c}\text { Interacted } \\
\text { Ratios } \\
\text { (3) }\end{array}$ \\
\hline \multicolumn{4}{|l|}{1 Year: } \\
\hline AboveThr & $\begin{array}{c}.302 \\
(1.941)\end{array}$ & $\begin{array}{c}2.592^{*} \\
(1.129)\end{array}$ & $\begin{array}{c}2.102^{\star} \\
(1.000)\end{array}$ \\
\hline AboveThr $\times$ Company Store Ratio & & & $\begin{array}{c}.029 \\
(.038)\end{array}$ \\
\hline \multicolumn{4}{|l|}{2 Years: } \\
\hline AboveThr & $\begin{array}{c}.896 \\
(2.546)\end{array}$ & $\begin{array}{r}3.287^{*} \\
(1.536)\end{array}$ & $\begin{array}{r}2.635^{+} \\
(1.355)\end{array}$ \\
\hline AboveThr $\times$ Company Store Ratio & & & $\begin{array}{c}.065 \\
(.052)\end{array}$ \\
\hline$N$ & 5,785 & 25,972 & 31,757 \\
\hline Company Store Ratio & $<1$ & $\geq 1$ & \\
\hline
\end{tabular}

Note. Results are estimated reduced-form effects on bankruptcy filings, in percentage points, with standard errors in parentheses. The sample is restricted to a \pm .5 -standard-deviation range around the credit-score threshold. Ratios of company stores in the borrower's home zip code to the number of establishments in that zip code are from the Census Bureau's ZIP Codes Business Patterns, with North American Industry Classification System codes of 522291 and 522390. All regressions include a quartic in the credit score interacted with the above-threshold dummy, demographic controls, and a full set of dummies for month of loan application. Demographic control variables and dummies for their missing values are included.

$+P<.1$.

${ }^{*} P<.05$.

are from regressions interacting AboveThr with the market-share proxy. ${ }^{21}$ In the high-market-share zip codes, we estimate effects of payday loan access that are large and significant at both 1 - and 2 -year horizons. ${ }^{22}$

Considering this collection of six tests together, we find that the positive effect of payday loan access on bankruptcy appears robust to optimal bandwidth algorithms, the functional form of the relationship with the credit score, many reasonable bandwidth choices, analysis using hazard models, the location of the threshold in the credit-score distribution, and the degree of competition in the local payday-lending market. Next we investigate the mechanisms that could give rise to this economically and statistically large effect.

${ }^{21}$ The coefficient on the interaction term in column 3 is statistically insignificant, but the main effect is close to the $N$-weighted average of the point estimates in columns 1 and 2.

${ }^{22}$ Applicants further below the threshold are less likely to be able to successfully reapply at a competing payday lender. Regressions with larger bandwidths, which include individuals with very low scores, will suffer less from this source of attenuation bias. 


\section{Mechanisms}

The typical payday loan is quite small: in our data set the mean and median principal amounts are approximately $\$ 300$. This section investigates the interesting question of how access to these loans can impact a cumulative financial outcome like bankruptcy.

\subsection{Assets and Liabilities of Bankruptcy Filers}

Debtors filing for bankruptcy protection must provide the court with schedules of detailed information documenting their assets and liabilities. ${ }^{23}$ This information is publicly available in PACER. We hand coded the data for a threshold sample of the 100 post-payday-application bankruptcy filers closest to the creditscore threshold on each side, plus those with equal scores at the endpoints. ${ }^{24}$ Table 7 reports summary information about their balance sheets.

Substantial empirical support has been found for strategic default to escape outstanding obligations, at least in the sense that debtors' pecuniary incentives to file correlate strongly with bankruptcy propensities. Fay, Hurst, and White (2002) find that each $\$ 1,000$ increase in the financial benefit of a bankruptcy filing increased the predicted probability of such a filing by .021 of a percentage point. Domowitz and Sartain (1999) and Gross and Souleles (2002) provide evidence that higher credit card debt predicts higher probabilities of bankruptcy, and White (2007) elaborates on this with supportive evidence.

The balance sheet data in Table 7 show substantial unsecured liabilities, with a mean of $\$ 27,880$, which indicates considerable possible financial benefit from a bankruptcy filing. However, by the time of the observed filings, the median approved borrower had no payday loan debt outstanding from the company that supplied our data. Thus, strategic default to escape outstanding payday loan balances does not appear to be directly implicated as the mechanism driving our results.

\subsection{Short-Run Responses}

The empirical analysis above focuses on the cumulative effect of payday loan access until 1 or 2 years after the first loan application. Some evidence on the determinants of bankruptcy points to motives that would induce shorter-run effects of credit access. First, applicants might (erroneously) believe that imminent debt erasure means it would be to their advantage to borrow as much as possible prior to a filing. Bankruptcy courts generally do not tolerate such short-run abuse of bankruptcy protection; regardless, the evidence from filers' balance sheets suggests that many payday loans are repaid or written off by the time of filing, which raises the question of how payday loans cause bankruptcy. Figure 8 reports point

\footnotetext{
${ }^{23}$ Debts not listed on the petition will not be discharged, and misrepresentation on the petition is grounds for dismissal, so debtors have strong incentives to be comprehensive.

${ }^{24}$ This resulted in review of 211 filings, 104 below the threshold and 107 above.
} 
Table 7

Payday Loan Applicants' Assets and Liabilities in Bankruptcy

\begin{tabular}{|c|c|c|}
\hline & $\begin{array}{c}\text { Below } \\
\text { Threshold }\end{array}$ & $\begin{array}{c}\text { Above } \\
\text { Threshold }\end{array}$ \\
\hline \multicolumn{3}{|l|}{ Total assets: } \\
\hline Mean & 105,905 & 131,149 \\
\hline Median & 105,784 & 125,788 \\
\hline $\mathrm{SD}$ & 83,156 & 80,009 \\
\hline \multicolumn{3}{|c|}{ Personal property: } \\
\hline Mean & 67,249 & 85,408 \\
\hline Median & 60,300 & 82,620 \\
\hline SD & 67,463 & 59,081 \\
\hline \multicolumn{3}{|c|}{ Real property: } \\
\hline Mean & 20,802 & 20,772 \\
\hline Median & 17,432 & 15,046 \\
\hline $\mathrm{SD}$ & 17,252 & 18,243 \\
\hline \multicolumn{3}{|l|}{ Liabilities: } \\
\hline Mean & 110,581 & 116,513 \\
\hline Median & 87,560 & 99,094 \\
\hline SD & 85,524 & 75,514 \\
\hline \multicolumn{3}{|c|}{ Secured debt: } \\
\hline Mean & 82,543 & 88,786 \\
\hline Median & 72,994 & 77,310 \\
\hline SD & 78,995 & 63,228 \\
\hline \multicolumn{3}{|c|}{ Unsecured debt: } \\
\hline Mean & 28,037 & 27,726 \\
\hline Median & 16,868 & 17,480 \\
\hline $\mathrm{SD}$ & 29,988 & 30,208 \\
\hline \multicolumn{3}{|c|}{ Company payday debt: } \\
\hline Mean & 11 & 159 \\
\hline Median & 0 & 0 \\
\hline $\mathrm{SD}$ & 66 & 335 \\
\hline \multicolumn{3}{|c|}{ Other payday debt: } \\
\hline Mean & 41 & 88 \\
\hline Median & 0 & 0 \\
\hline SD & 179 & 285 \\
\hline
\end{tabular}

Note. Results, in dollars, are from bankruptcy petition filings for 211 payday loan applicants (104 below and 107 above the passing credit score threshold) who filed for bankruptcy after their first payday loan application. The samples are not exactly balanced because of ties in scores. Data are from the Public Access to Court Electronic Records database matched to records from a payday loan company. 


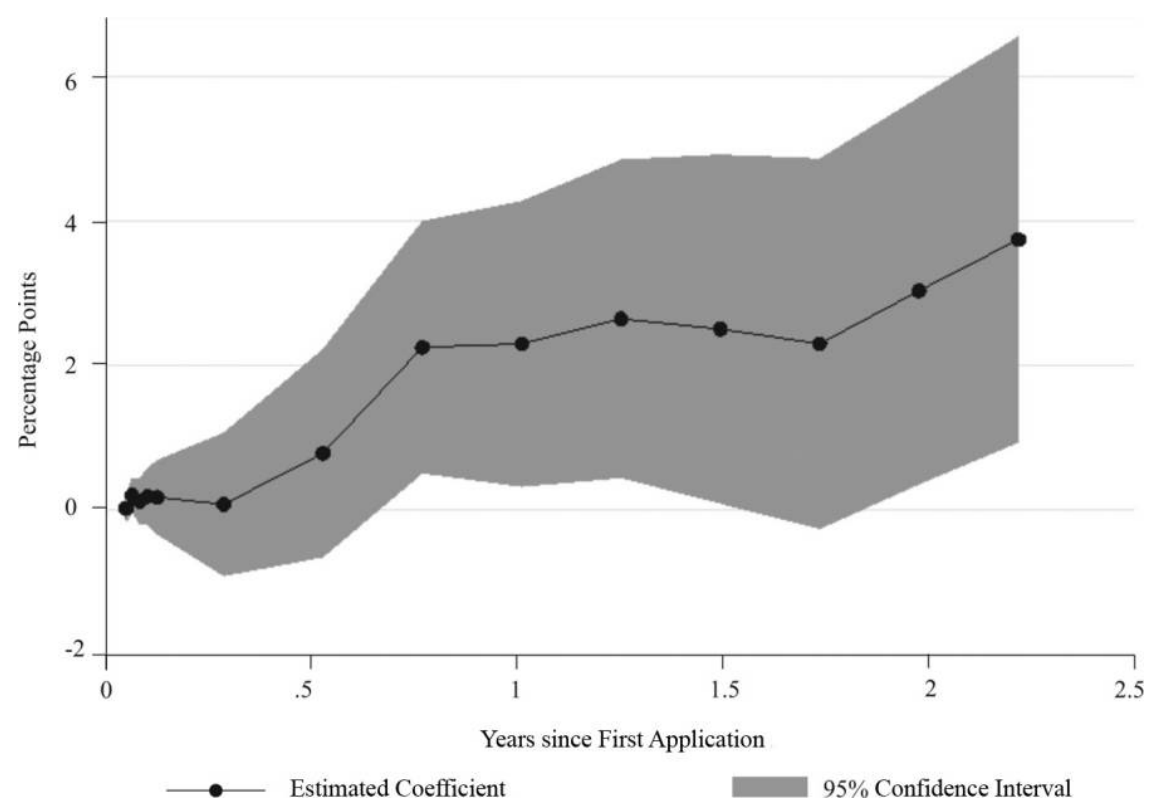

Figure 8. Long-run effects of payday loans on bankruptcies

estimates of the effect of payday loan access on bankruptcy filing on time horizons from several days to several years. It confirms that the directional effects are robust to the time horizon we examine, and it displays no disproportionate short-run response. Estimated coefficients are from the reduced-form specification, equation (3), with \pm .5-standard-deviation windows around the threshold.

A second possible reason that payday loan access could have a short-run effect on bankruptcy concerns filing fees. Mann and Porter (2010) argue that filing fees affect the chapter of a bankruptcy filing. Gross, Notowidigdo, and Wang (2014) use a natural experiment to estimate the impact of positive liquidity shocks on filing rates. They find large very short-run effects, which supports the view that sometimes liquidity infusions can be used to pay filing fees. Together, the balance sheet information shown in Table 7 and the estimates at various time horizons reported in Table 6 and Figure 8 suggest that a different mechanism is more likely to give rise to the effect of payday loan access on bankruptcy.

\subsection{Subsequent Payday Loan Borrowing and the Cash Flow Hypothesis}

This section investigates the possibility that payday loan access increases the personal bankruptcy rate via household cash flow. Table 8 reports the effect of payday loan access on number of applications, total dollar amount borrowed, and total finance charges at the lender. Here we use the same regression specifications as our main results in Table 4. Approval for one payday loan evidently 


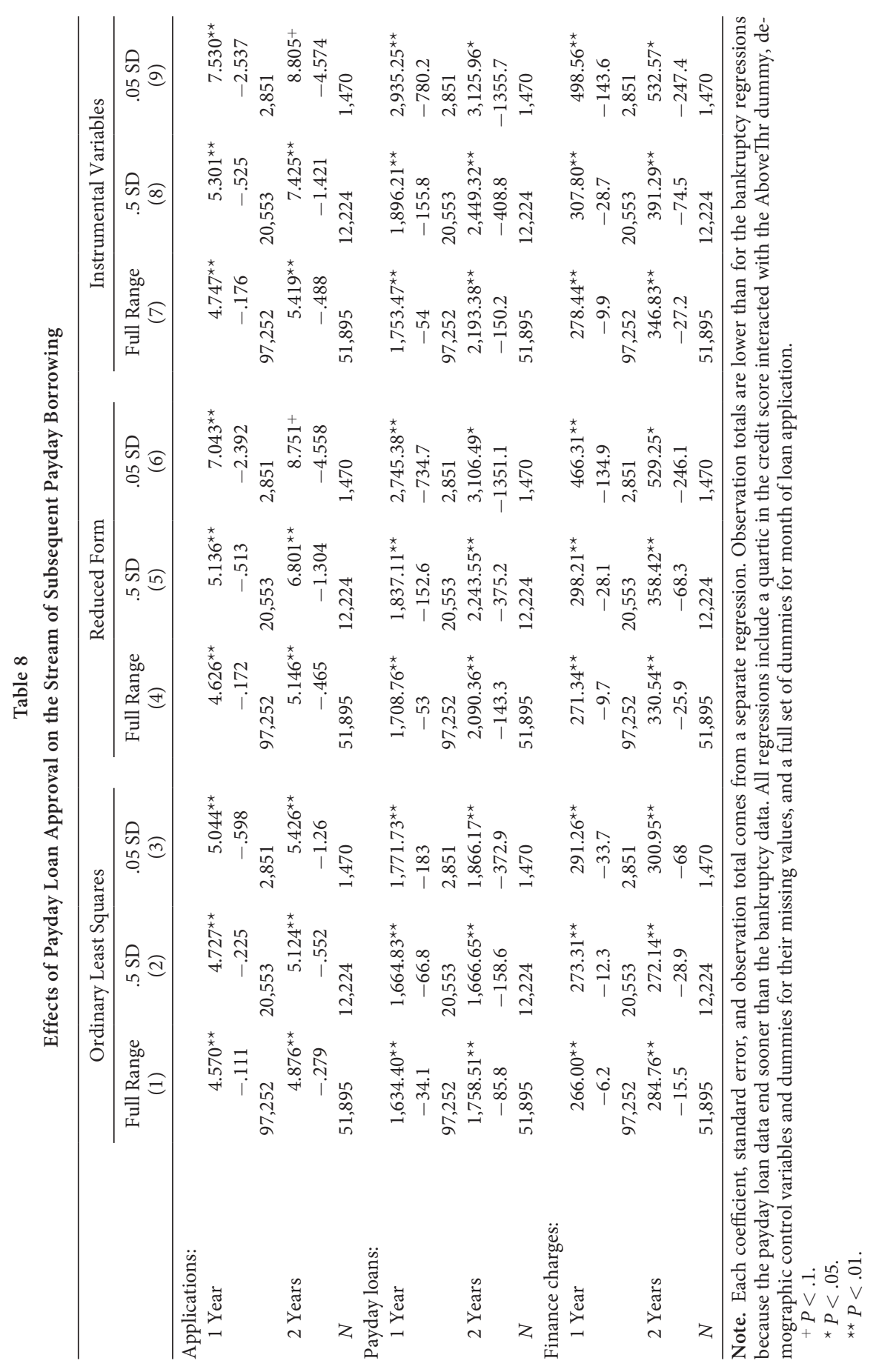

This content downloaded from 129.059.122.098 on February 12, 2020 11:06:05 AM All use subject to University of Chicago Press Terms and Conditions (http://www.journals.uchicago.edu/t-and-c). 
results in substantial follow-on activity. The reduced-form regression with range restricted to \pm .5 standard deviations implies that the approval of a first-time payday loan application results in an average of 5.1 more payday loan applications at the company within the next year. Borrowing is increased by $\$ 1,837$ over that 1 -year horizon, while finance charges paid to the company increase by $\$ 298$ over the same period. These results are all significant at the 1 percent level.

The effect on finance charges speaks most clearly to the mechanism behind the bankruptcy effect. Suppose bankruptcy filers' unsecured debt carries a 15 percent APR. ${ }^{25}$ Then, drawing again on data from Table 7 , we find that, over the first year after a payday loan application, the interest burden from payday loans would have averaged $\$ 298 /(\$ 27,880 \times 15$ percent $)=7$ percent of those individuals' annual liquid debt interest burden. ${ }^{26}$ Moreover, credit card debt service might be easier to postpone, for example, by remitting only a minimum payment. This 7 percent increase in the debt-related household cash flow burden could suffice to tip financially stressed payday loan applicants into bankruptcy.

\subsection{Collections Pressure and the Automatic Stay}

One complementary possibility is that payday loan borrowing and default results in increased collections activity, ${ }^{27}$ and the collections activity motivates dunned borrowers to seek protection via the bankruptcy code's automatic stay. The automatic stay prohibits any collections activity by creditors holding secured and unsecured claims. Over half of the borrowers in our data have a payday loan that results in a bounced check within 1 year of their first loan, and over 30 percent have a loan that is written off and sold to a collection agency, so avoiding collections pressure is plausibly an important motive.

We investigate this hypothesized mechanism in Figure 9 and Online Appendix Figures OA9-OA11. Figure 9 plots the daily rates of default on payday loans, measured by bouncing of the postdated check, versus the number of days from the bankruptcy-filing date to the loan due date. (Loans due before the filing date appear to the left of 0 .) The figures have two main features, and they give rise to a two-part interpretation. First, bounced checks are common for this population: among loans due within 100 days of the bankruptcy filing, over 10 percent re-

\footnotetext{
${ }^{25}$ The Federal Reserve's G19 data series on consumer credit implies a debt-weighted average nominal interest rate on credit card debt of about 15 percent. This could imply an underestimate of the liquid debt service burden for payday loan applicants if they have higher-rate cards or disproportionately pay penalty interest rates, or it could be an overestimate if payday loan borrowers disproportionately let interest accrue while making small payments and then eventually default at high rates on their credit cards.

${ }^{26}$ Almost identically, elsewhere we report median scheduled minimum debt payments (including principal and interest) for the population of payday loan applicants of $\$ 4,000$ per year (Bhutta, Skiba, and Tobacman 2015).

${ }^{27}$ It is possible that the payday lender or the third party are aggressive in collections practices, though threatening physical harm is prohibited by the Fair Debt Collection Practices Act. We found no published papers quantifying such threats, although of course it could be possible. We understand that the payday lender's internal collections department attempts to collect on the debt for a few weeks and then sells the debt to a third-party collection agency.
} 


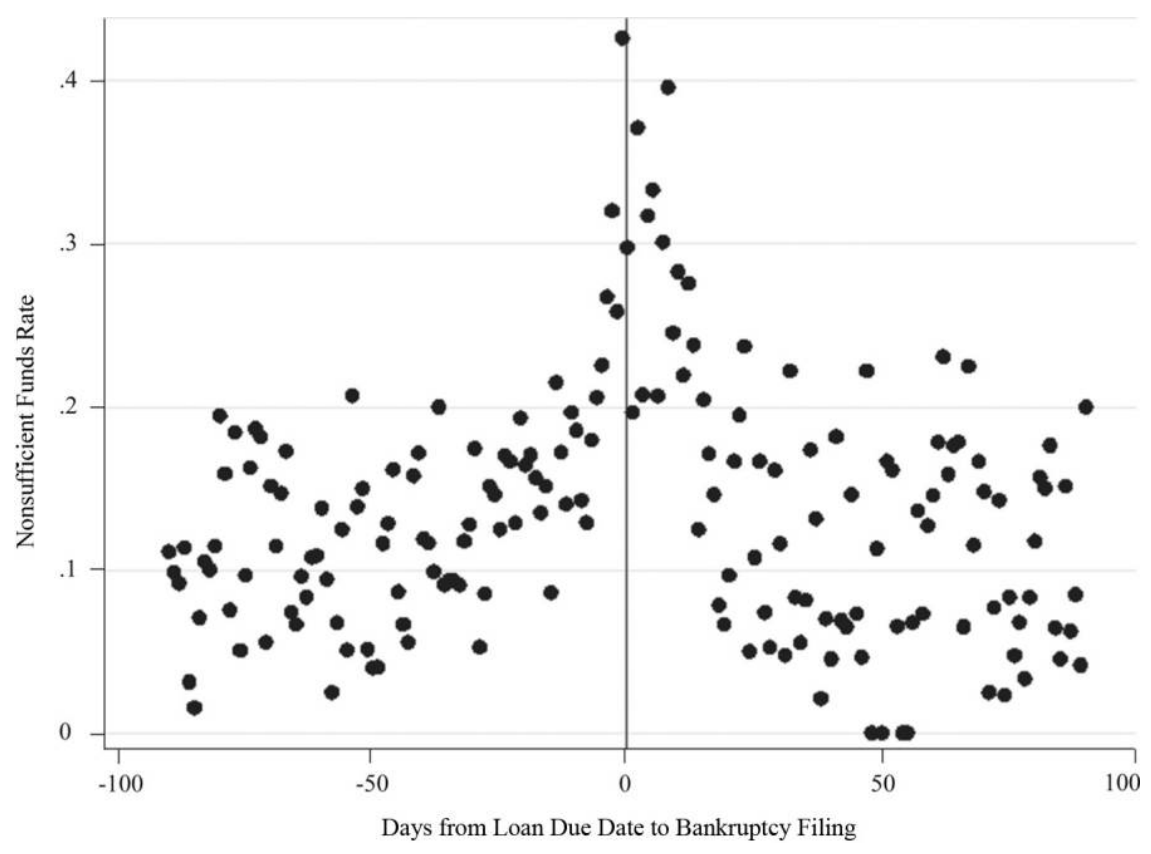

Figure 9. Payday loan default rates around the bankruptcy filing date

sult in bounced checks. If desire for an automatic stay motivates the bankruptcy filing, borrowers apparently wait a long time after payday-related collections activity begins before they complete their bankruptcy filings, and defaults continue to occur after the filings. Second, within a week of the bankruptcy filing on either side, bounced-check rates abruptly and briefly spike above 30 percent. It is possible that those filers coordinated the timing of their bankruptcy filings and bounced checks so as to minimize the duration of default-related collections activity. Of course, it is also possible that broader financial distress brought about by both the payday loan default and the bankruptcy filing and/or the advice given by the payday borrowers' bankruptcy lawyers resulted in coordinated timing of these events. ${ }^{28}$

${ }^{28}$ Figures OA9-OA11 complement this evidence. They show that many borrowers would have benefited from the automatic stay long before their bankruptcy filings, while some were newly exposed to collections activity right before their filings. Figures OA9-OA11 also show similar patterns for collections by the payday lender and collections by whoever buys the delinquent debt after 90 days of internal collections. 


\section{Discussion}

\subsection{Interpretation and Related Literature}

Our findings complement and extend the rich but unsettled literatures on the effects of payday loan access and the causes of bankruptcy filings, which we discuss in turn. Research on the impact of payday loans comes to disparate conclusions (Caskey 2012). Zinman (2010), Morse (2011), and Carter and Skimmyhorn (2017) generally find beneficial consequences of payday loan access. Carrell and Zinman (2014), Melzer (2011), and Campbell, Martínez-Jerez, and Tufano (2012) generally find the opposite. Lefgren and McIntyre (2009), Morgan, Strain, and Seblani (2012), Bhutta (2014), and Bhutta, Skiba, and Tobacman (2015) obtain null or mixed effects.

Many forces could give rise to this diversity of findings, from variation in the source of identification to differences in the affected populations. Three papers are particularly close to ours. Elsewhere, we use the same identification strategy and examine effects on variables reported to a prime credit bureau (Bhutta, Skiba, and Tobacman 2015). We find economically small effects on credit scores, balances, and delinquencies, but the standard errors are large enough to be compatible with the effects on bankruptcy that we document here. ${ }^{29}$ In addition, we show that our sample of payday loan applicants was experiencing longstanding financial distress at the time of their first payday loan applications, with low availability of credit cards, high rates of recent delinquencies, and credit scores that had on average fallen into the bottom quartile of the national distribution for at least 5 years.

Lefgren and McIntyre (2009) investigate the relationship between crosssectional geographic characteristics and bankruptcy rates, using state-level and zip-code-level variation. Their striking primary results concern wage garnishment rules, household characteristics, and legal culture, with effects of wage garnishment restrictions amounting to 42 percent of baseline bankruptcy rates. In addition, they report a statistically insignificant but positive relationship between legal payday lending in a state and bankruptcy rates. Payday loan access raises the state rate by .12 bankruptcies per thousand residents off a baseline rate of 4.46 . Morgan, Strain, and Seblani (2012), working with state-year variation in payday loan bans and difference-in-difference regressions, estimate that bans reduce Chapter 13 filing rates by between one-sixth and one-third.

If payday loan bans affect bankruptcy propensities only for payday loan borrowers, and the payday loan borrowing rate in states without bans is 10 percent, then the quantitative findings in Lefgren and McIntyre (2009) and Morgan, Strain, and Seblani (2012) should be scaled up by an order of magnitude to compare with our findings here, since we estimate effects only on payday loan applicants. This rescaling would imply effect sizes of 1.2 bankruptcies (Lefgren and

${ }^{29}$ In Bhutta, Skiba, and Tobacman (2015), we do not examine bankruptcy as an outcome because of data limitations: bankruptcy flags appear with irregular timing in the matched credit bureau data, and our strategy to match multiple data sets resulted in a sample with too few bankruptcy filings. 
McIntyre 2009) and .48-.93 Chapter 13 bankruptcies (Morgan, Strain, and Seblani 2012) per thousand payday loan applicants, smaller than our findings here but of the same order of magnitude.

\subsection{Welfare Implications}

The welfare effects of the indebtedness and bankruptcies resulting from access to payday loans are difficult to measure and could in principle be positive or negative. Since bankruptcy is a form of social insurance, the net social costs may lie in transactions costs and externalities elsewhere in the credit markets. In particular, access to payday loans may cause other unsecured debt to become uncollectable, which drives up equilibrium interest rates on other forms of credit.

One window into the private costs and benefits of bankruptcy filing is provided by the chapter of filing and the disposition of the case. Many of the benefits of a Chapter 13 filing accrue only if and when the associated payment plan is completed and remaining debts are discharged. ${ }^{30}$ Chapter 13 filers often instead have their cases dismissed (or converted to Chapter 7) prior to discharge for failure to keep up the regular payments toward a Chapter 13 plan. Dobbie and Song (2015) find that completing a Chapter 13 plan and thus discharging remaining debts relative to filing for Chapter 13 and having the case dismissed improves subsequent earnings and lowers mortality rates.

We test for differential effects by bankruptcy chapter $(7,13$, or 13 and dismissed) in Table 9. Columns 1-4 report estimated treatment effects analogous to those in Table 4. Columns 1 and 2 show a significant impact of payday loan access on Chapter 13 but not on Chapter 7 filings. Columns 3 and 4 show that the effect on Chapter 13 filings is primarily attributable to cases that were dismissed.

Similar results appear for the multinomial logit specifications, which respect more of the structure of the debtor's choice environment. For various sets of controls, the estimates are most reliably statistically significant for Chapter 13 filings that are eventually dismissed. However, all of the point estimates for effects on Chapter 7 bankruptcy are also positive, and the standard errors are always large enough that we cannot statistically reject the hypothesis that the 7, 13, and 13 and dismissed estimates are the same. ${ }^{31}$

One other possible window into welfare implications is provided by analysis of heterogeneous treatment effects. Table OA14 reports estimates by gender, race, and homeownership status from the reduced-form specification with a \pm .5-standard-deviation credit-score range. Column 1 repeats the benchmark numbers from regression results in Table 4 for comparison. In the other columns, sample sizes shrink so standard errors are large and no effects are statistically significant. Column 12 examines effects on service members, because of concerns by regulators, elected representatives, and the Department of Defense (2006) that

\footnotetext{
${ }^{30} \mathrm{We}$ are very grateful to an anonymous referee for highlighting this point and suggesting the following analysis.

${ }^{31}$ Tables OA11-OA13 report optimal bandwidth version of the regressions in Table 9, analogous to those in Table 5, for Chapter 7 filings, Chapter 13 filings, and Chapter 13 filings that were eventually dismissed. Figures OA3-OA8 similarly replicate the main figures.
} 


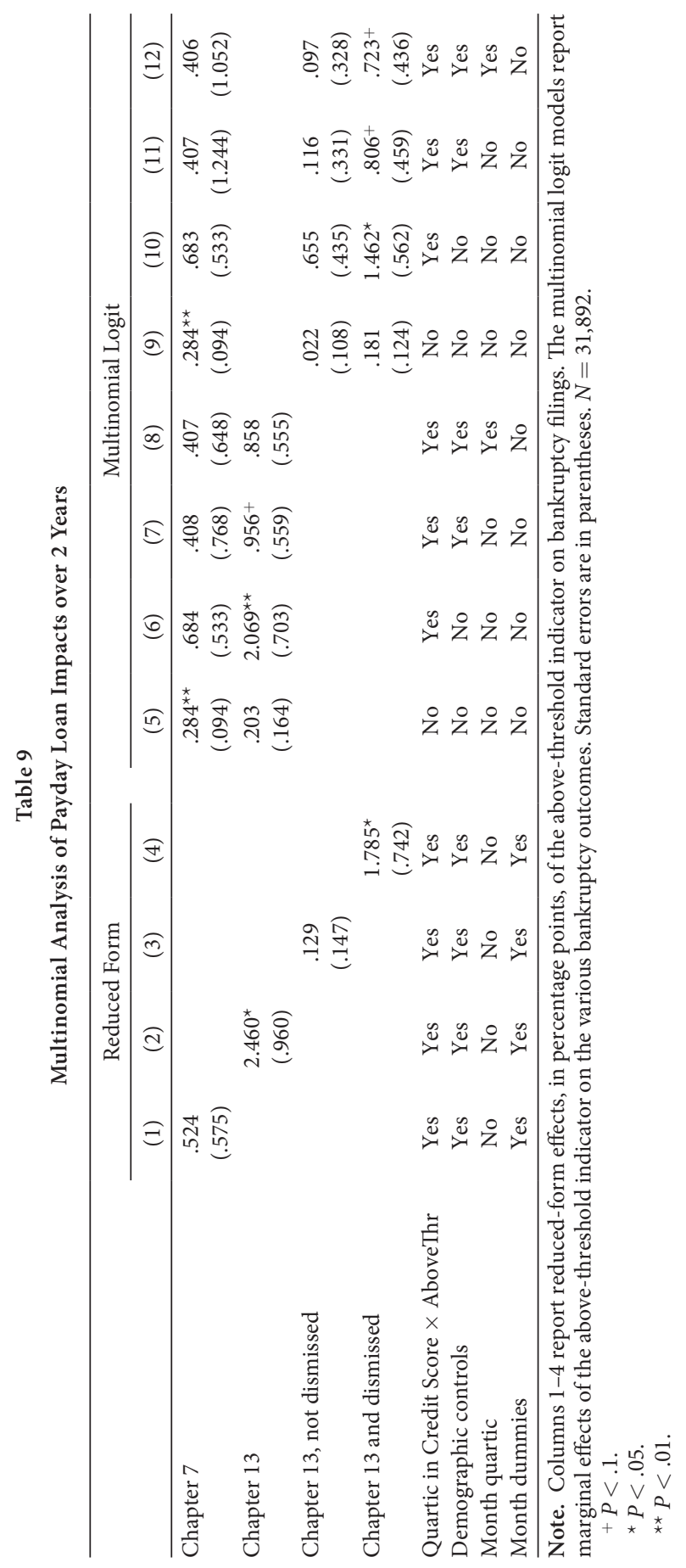

This content downloaded from 129.059.122.098 on February 12, 2020 11:06:05 AM All use subject to University of Chicago Press Terms and Conditions (http://www.journals.uchicago.edu/t-and-c). 
payday loans disproportionately affect military personnel. ${ }^{32}$ We estimate an economically large positive effect of payday loans on service members' bankruptcies, which (not surprising given the small sample) is statistically insignificant.

More broadly, Han and Li (2011) show that the available terms of borrowing are worse (for example, credit card interest rates are higher by 116 basis points) for households that have filed for bankruptcy than households that have not. Similarly, Han, Keys, and Li (2011) find that direct-mail credit card offers generally worsen for recent bankruptcy filers. These empirical results combine the effect of whatever led to the bankruptcy filing with the effect of the bankruptcy filing itself. Dobbie and Song (2015) and Dobbie, Goldsmith-Pinkham, and Yang (2017) focus on the quasi-experimental effect of a Chapter 13 filing alone and find it to be highly beneficial, reducing foreclosure rates, mortality, civil judgments, and repossessions and increasing earnings, homeownership, and credit scores.

Taken together, the related literature and our estimates carry the following interpretation. The bankruptcy filings induced by payday loan access cause other debt to become uncollectable for these borrowers, which may cause interest rates to rise for other ex ante indistinguishable borrowers, so the externalities are unlikely to be positive. The net private costs are difficult to ascertain, but it appears that the payday applicants induced to file for bankruptcy receive benefits from its social insurance aspects that are toward the low end. Regardless, a bankruptcy filing is a rare but interesting and high-consequence indicator of financial distress.

\section{Conclusion}

We find that payday loan applicants barely approved for their first loans file for bankruptcy protection significantly more often than barely rejected first-time applicants. The magnitude of the effect is economically nontrivial, representing an increase of about 1 percentage point in the bankruptcy-filing rate. Opportunities for rejected applicants to substitute with credit elsewhere (Carter 2015; Bhutta, Goldin, and Homonoff 2016) imply that our quantitative findings are lower bounds on the true effects, but by estimating the effects as a function of this firm's zip-code-level market share, we document that the bias is likely to be small.

Equally importantly, we evaluate four major candidate mechanisms for the increase in bankruptcy rates. We find the most support for a mechanism that to our knowledge is novel in the literature, that is, reductions in household cash flow due to the debt service burden. Taken together, our results are consistent with the view that payday loans exacerbate financial distress and that household cash flow should be more intensively explored as a driver of bankruptcy-filing decisions. First-time payday loan approval causes significant additional highinterest-rate borrowing, and the consequent interest burden may worsen house-

\footnotetext{
${ }^{32} \mathrm{We}$ code an applicant as a member of the military if (ignoring capitalization) his or her employer name contains "Marines," "Marine Corps," "Air Force," "USAF," or "Army" but not "Salv" or if it contains "Navy" but not "Old Navy." This yields 2,332 service member observations in the full data set and 638 observations in the 31,892 observations within .5 standard deviations of the threshold.
} 
hold cash flow sufficiently to induce bankruptcy. The bankruptcies that result are often dismissed Chapter 13 filings that do not result in a discharge, providing less benefit to the debtors. The welfare implications of our empirical findings depend on difficult-to-estimate parameters like the private and social net costs of bankruptcy filings.

Our research also informs the ongoing public debate related to payday loan regulation. The Consumer Financial Protection Bureau issued a payday loan rule requiring lenders to "reasonably determine that the consumer has the ability to repay the loan" (12 C.F.R. sec. 1041 [2017]). The date for lenders to comply with these rules was set for August 2019. The current administration suspended the rule indefinitely before implementation and, in the spring of 2019, proposed rolling back that portion of the final payday regulation rule. Our findings contribute to the body of research that policy makers may consider in moving forward with the regulation of payday loans. We hope that these findings, and the questions they raise, advance ongoing discussion about payday lending and the determinants of bankruptcy.

\section{References}

Agarwal, Sumit, Paige Marta Skiba, and Jeremy Tobacman. 2009. Payday Loans and Credit Cards: New Liquidity and Credit Scoring Puzzles? American Economic Review: Papers and Proceedings 99:412-17.

Angrist, Joshua D., and Victor Lavy. 1999. Using Maimonides' Rule to Estimate the Effect of Class Size on Scholastic Achievement. Quarterly Journal of Economics 114:533-75.

Ausubel, Lawrence M. 1999. Adverse Selection in the Credit Card Market. Unpublished manuscript. University of Maryland, Department of Economics, College Park.

Bhutta, Neil. 2014. Payday Loans and Consumer Financial Health. Lournal of Banking and Finance 47:230-42.

Bhutta, Neil, Jacob Goldin, and Tatiana Homonoff. 2016. Consumer Borrowing after Payday Loan Bans. Iournal of Law and Economics 59:225-59.

Bhutta, Neil, Paige Marta Skiba, and Jeremy Tobacman. 2015. Payday Loan Choices and Consequences. Iournal of Monev, Credit, and Banking 47:223-60.

Calonico, Sebastian, Matias D. Cattaneo, and Rocío Titiunik. 2014a. Robust Data-Driven Inference in the Regression-Discontinuity Design. Stata Journal 14:909-46.

- 2014b. Robust Nonparametric Confidence Intervals for Regression-Discontinuity Designs. Econometrica 82:2295-2326.

Campbell, Dennis, F. Asís Martínez-Jerez, and Peter Tufano. 2012. Bouncing out of the Banking System: An Empirical Analysis of Involuntary Bank Account Closures. Lournal of Banking and Finance 36:1224-35.

Carrell, Scott, and Jonathan Zinman. 2014. In Harm's Way? Payday Loan Access and Military Personnel Performance. Review of Financial Studies 27:2805-40.

Carter, Susan Payne. 2015. Payday Loan and Pawnshop Usage: The Impact of Allowing Payday Loan Rollovers. Lournal of Consumer Affairs 49:436-56.

Carter, Susan Payne, and William Skimmyhorn. 2017. Much Ado about Nothing? New Evidence on the Effects of Payday Lending on Military Members. Review of Economics and Statistics 99:606-21. 
Caskey, John P. 1991. Pawnbroking in America: The Economics of a Forgotten Credit Market. Lournal of Monev, Credit, and Banking 23:85-99.

1994. Fringe Banking: Check-Cashing Outlets, Pawnshops, and the Poor. New York: Russell Sage Foundation.

-2001. Payday Lending. Journal of Financial Counseling and Planning 12:1-14.

2005. Fringe Banking and the Rise of Payday Lending. Pp. 17-45 in Credit Markets for the Poor, edited by Patrick Bolton and Howard Rosenthal. New York: Russell Sage Foundation.

. 2012. Payday Lending: New Research and the Big Question. Pp. 681-706 in The Oxford Handbook of the Economics of Poverty, edited by Phillip N. Jefferson. New York: Oxford University Press.

Department of Defense. 2006. Report on Predatory Lending Practices Directed at Members of the Armed Forces and Their Dependents. August 9. Washington, DC: Department of Defense. https://archive.defense.gov/pubs/pdfs/Report_to_Congress_final.pdf.

Dobbie, Will, Paul Goldsmith-Pinkham, and Crystal Yang. 2017. Consumer Bankruptcy and Financial Health. Review of Economics and Statistics 99:853-69.

Dobbie, Will, and Jae Song. 2015. Debt Relief and Debtor Outcomes: Measuring the Effects of Consumer Bankruptcy Protection. American Economic Review 105:1272-1311.

Domowitz, Ian, and Robert L. Sartain. 1999. Determinants of the Consumer Bankruptcy Decision. Lournal of Finance 54:403-20.

Elliehausen, Gregory, and Edward C. Lawrence. 2001. Payday Advance Credit in America: An Analysis of Customer Demand. Monograph No. 35. Georgetown University, McDonough School of Business, Credit Research Center, Washington, DC.

Fay, Scott, Erik Hurst, and Michelle J. White. 2002. The Household Bankruptcy Decision. American Economic Review 92:706-18.

Flannery, Mark, and Katherine Samolyk. 2005. Payday Lending: Do the Costs Justify the Price? Working Paper No. 2005-09. Federal Deposit Insurance Corporation, Center for Financial Research, Washington, DC.

Gross, Tal, Matthew J. Notowidigdo, and Jialan Wang. 2014. Liquidity Constraints and Consumer Bankruptcy: Evidence from Tax Rebates. Review of Economics and Statistics 96:431-43.

Gross, David B., and Nicholas S. Souleles. 2002. An Empirical Analysis of Personal Bankruptcy and Delinquency. Review of Financial Studies 15:319-47.

Hahn, Jinyong, Petra Todd, and Wilbert Van der Klaauw. 2001. Identification and Estimation of Treatment Effects with a Regression-Discontinuity Design. Econometrica 69:201-9.

Han, Song, Benjamin J. Keys, and Geng Li. 2011. Credit Supply to Personal Bankruptcy Filers: Evidence from Credit Card Mailings. Working paper. Federal Reserve Board, Divisions of Research and Statistics and Monetary Affairs, Washington, DC.

Han, Song, and Geng Li. 2011. Household Borrowing after Personal Bankruptcy. Lournal of Monev, Credit, and Banking 43:491-517.

Himmelstein, David U., Deborah Thorne, Elizabeth Warren, and Steffie Woolhandler. 2009. Medical Bankruptcy in the United States, 2007: Results of a National Study. American Journal of Medicine 122:741-46.

Imbens, Guido, and Karthik Kalyanaraman. 2012. Optimal Bandwidth Choice for the Regression Discontinuity Estimator. Review of Economic Studies 79:933-59.

Imbens, Guido W., and Thomas Lemieux. 2008. Regression Discontinuity Designs: A Guide to Practice. Lournal of Econometrics 142:615-35. 
Karlan, Dean S., and Jonathan Zinman. 2008. Credit Elasticities in Less-Developed Economies: Implications for Microfinance. American Economic Review 98:1040-68.

- 2009. Observing Unobservables: Identifying Information Asymmetries with a Consumer Credit Field Experiment. Econometrica 77:1993-2008.

- 2010. Expanding Credit Access: Using Randomized Supply Decisions to Estimate the Impacts. Review of Financial Studies 23:433-64.

Lefgren, Lars, and Frank McIntyre. 2009. Explaining the Puzzle of Cross-State Differences in Bankruptcy Rates. Journal of Law and Economics 52:367-93.

Lusardi, Annamaria, and Carlo de Bassa Scheresberg. 2013. Financial Literacy and HighCost Borrowing in the United States. Working Paper No. 18969. National Bureau of Economic Research, Cambridge, MA.

Mann, Ronald J., and Katherine Porter. 2010. Saving Up for Bankruptcy. Georgetown Law Journal 98:289-339.

McCrary, Justin. 2008. Manipulation of the Running Variable in the Regression Discontinuity Design: A Density Test. Journal of Econometrics 142:698-714.

Melzer, Brian T. 2011. The Real Costs of Credit Access: Evidence from the Payday Lending Market. Quarterlv Journal of Economics 126:517-55.

Morgan, Donald P., Michael R. Strain, and Ihab Seblani. 2012. How Payday Credit Access Affects Overdrafts and Other Outcomes. Lournal of Monev, Credit, and Banking 44:519-31.

Morrison, Edward R., Arpit Gupta, Lenora Olson, Lawrence Cook, and Heather Keenan. 2013. Health and Financial Fragility: Evidence from Car Crashes and Consumer Bankruptcy. Research Paper No. 655. University of Chicago Law School, Coase-Sandor Institute for Law and Economics, Chicago.

Morse, Adair. 2011. Payday Lenders: Heroes or Villains? Lournal of Financial Economics 102:28-44.

Pew Charitable Trusts. 2012. Payday Lending in America: Who Borrows, Where They Borrow, and Why. Washington, DC: Pew Charitable Trusts.

Porter, Jack. 2003. Estimation in the Regression Discontinuity Model. Working paper. Harvard University, Department of Economics, Cambridge, MA.

Skiba, Paige Marta, and Jeremy Tobacman. 2008. The Profitability of Payday Lending. Working paper. Vanderbilt University Law School, Nashville.

Stegman, Michael A., and Robert Faris. 2003. Payday Lending: A Business Model That Encourages Chronic Borrowing. Economic Development Ouarterlv 17:8-32.

Thistlethwaite, Donald L., and Donald T. Campbell. 1960. Regression-Discontinuity Analysis: An Alternative to the Ex-Post Facto Experiment. Iournal of Educational Psychology 51:309-17.

White, Michelle J. 2007. Bankruptcy Reform and Credit Cards. Lournal of Economic Perspectives 21(4):175-200.

Zinman, Jonathan. 2010. Restricting Consumer Credit Access: Household Survey Evidence on Effects around the Oregon Rate Cap. Lournal of Banking and Finance 34:54656. 